\title{
Apolipoprotein A1/C3/A5 haplotypes and serum lipid levels
}

\author{
Rui-Xing Yin ${ }^{1^{*}}$, Yi-Yang Li $\mathrm{Li}^{1,2}$ and Chao-Qiang Lai ${ }^{3^{*}}$
}

\begin{abstract}
Background: The association of single nucleotide polymorphisms (SNPS) in the apolipoprotein (Apo) A1/C3/A4/A5 gene cluster and serum lipid profiles is inconsistent. The present study was undertaken to detect the association between the ApoA1/C3/A5 gene polymorphisms and their haplotypes with serum lipid levels in the general Chinese population.

Methods: A total of 1030 unrelated subjects (492 males and 538 females) aged 15-89 were randomly selected from our previous stratified randomized cluster samples. Genotyping of the ApoA1 -75 bp G>A, ApoC3 3238C>G, ApoA5 -1131T>C, ApoA5 c.553G>T and ApoA5 c.457G >A was performed by polymerse chain reaction and restriction fragment length polymorphism combined with gel electrophoresis, and then confirmed by direct sequencing. Pair-wise linkage disequilibria and haplotype analysis among the five SNPs were estimated.

Results: The levels of high-density lipoprotein cholesterol (HDL-C) and ApoA1 were lower in males than in femailes $(P<0.05$ for each). The allelic and genotypic frequencies of the SNPs were no significant difference between males and females except ApoC3 3238C >G. There were 11 haplotypes with a frequency $>1 \%$ identified in the cluster in our population. At the global level, the haplotypes comprised of all five SNPs were significantly associated with all seven lipid traits. In particular, haplotype G-G-C-C-A (6\%; in the order of ApoA5 c.553G>T, ApoA5 c.457G>A, ApoA5 -1131T>C, ApoC3 3238C>G, and ApoA1-75bp G>A) and G-A-T-C-G (4\%) showed consistent association with total cholesterol (TC), low-density lipoprotein cholesterol (LDL-C), ApoA1, ApoB, and the ApoA1/ApoB ratio. In addition, carriers of haplotype G-G-T-C-G (26\%) had increased serum concentration of HDL-C and ApoA1, whereas carriers of G-G-C-G-G (15\%) had high concentrations of TC, triglyceride (TG) and ApoB. We also found that haplotypes with five SNPs explain much more serum lipid variation than any single SNP alone, especially for TG (4.4\% for haplotype vs. 2.4\% for - $1131 \mathrm{~T}>\mathrm{C}$ max based on R-square) and HDL-C (5.1\% for haplotype vs. $0.9 \%$ for c.553G $>$ T based on R-square). Serum lipid parameters were also correlated with genotypes and several environment factors.
\end{abstract}

Conclusions: Several common SNPs and their haplotypes in the ApoA1/C3/A5 gene cluster are closely associated with modifications of serum lipid parameters in the general Chinese population.

\section{Introduction}

Dyslipidemia is a common metabolic disorder that may result from abnormalities in the synthesis, processing and catabolism of lipoprotein particles. Elevated plasma total cholesterol (TC) [1], triglyceride (TG) [2], low-density lipoprotein cholesterol (LDL-C) [3], and

\footnotetext{
* Correspondence: yinruixing@yahoo.com.cn; chao.lai@tufts.edu 'Department of Cardiology, Institute of Cardiovascular Diseases, the First Affiliated Hospital, Guangxi Medical University, 22 Shuangyong Road, Nanning 530021, Guangxi, People's Republic of China

${ }^{3}$ Nutrition and Genomics Laboratory, Jean Mayer USDA HNRCA at Tufts University, Boston, MA 02111-1524, USA Full list of author information is available at the end of the article
}

apolipoprotein (Apo) B [4], together with decreased levels of ApoA1 [4] and high-density lipoprotein cholesterol (HDL-C) [5] are associated with an increased risk of coronary artery disease (CAD). A number of epidemiological studies have shown that in addition to environmental factors, genetic mechanisms may play a role in determining susceptibility to dyslipidemia [6]. The heritability estimates of the interindividual variation in plasma lipid phenotypes from both twin and family studies are in the range of 40-60\% [7], suggesting a considerable genetic contribution, and discovery of the genes
C Biomed Central 
that contribute to these changes may lead to a better understanding of these processes.

ApoA1 is the predominant protein component of HDL-C, and is involved in the activation of lecithin: cholesterol acyltransferase, which mediate the reverse cholesterol transport from peripheral tissues to the liver [8]. ApoC3 is a major component of TG-rich lipoproteins (chylomicrons and very low density lipoprotein) and a minor component of HDL. The mature 79amino-acid ApoC3 protein is synthesized predominantly in the liver but also to a lesser extent in the intestine. In vitro studies have indicated that ApoC3 is a noncompetitive inhibitor of lipoprotein lipase, thereby suggesting an important role in the catabolism of TG-rich lipoproteins [9]. ApoA5 is a secreted protein present in human serum and is associated with specific lipoprotein particles. It was detectable in very low-density lipoprotein, $\mathrm{HDL}$, and chylomicrons. Serum ApoA5 is very low compared with other apolipoproteins [10]. Human ApoA1/ $\mathrm{C} 3 / \mathrm{A} 5$ gene resides in the ApoA1/C3/A4/A5 gene cluster, a short region on chromosome 11q23-q24 [11,12]. The ApoA1/C3/A4/A5 gene cluster has been identified as a candidate region for hyperlipidemia in particular for hypertriglyceridemia and atherosclerosis $[12,13]$. The association between single nucleotide polymorphisms (SNPs) in the ApoA1/C3/A4/A5 gene cluster and plasma or serum lipid levels in humans has been evaluated in a large number of studies [13-30]. However, previous findings on the association of the SNPs in this gene cluster with the changes in plasma lipid levels are inconsistent [31-38]. Many of previous studies for this gene cluster come from studies of hyperlipidemic subjects $[14,17,18,25,26,29,33,38]$ and CAD patients $[13,19,21,23,34,36,37]$. Studies of differences in the association between ApoA1/C3/A5 gene polymorphisms and serum lipid levels in normolipidemic men and women are extremely limited. Therefore, the aim of the present study was to detect the polymorphisms of ApoA1 -75 bp G>A (rs1799837), ApoC3 3238C >G (rs5128), ApoA5 $-1131 \mathrm{~T}>\mathrm{C}$ (rs662799), ApoA5 c.553G $>\mathrm{T}$ (rs2075291) and ApoA5 c.457G>A (rs3135507) and the association of their haplotypes and serum lipid levels in the general Chinese population.

\section{Materials and methods Study populations}

A total of 1030 unrelated subjects who reside in 16 villages in Napo County, Guangxi Zhuang Autonomous Region, People's Republic of China were randomly selected from our previous stratified randomized cluster samples [39]. The age of the subjects ranged from 15 to 89 years, with an average age of $43.30 \pm 17.69$ years. There were 492 males and 538 females. All of the subjects were rural agricultural workers. The subjects had no evidence of diseases related to atherosclerosis, CAD and diabetes. None of them had been treated with $\beta$ adrenergic blocking agents and lipid-lowering drugs such as statins or fibrates. The present study was approved by the Ethics Committee of the First Affiliated Hospital, Guangxi Medical University. Informed consent was obtained from all subjects after they received a full explanation of the study.

\section{Epidemiological survey}

The survey was carried out using internationally standardized methods. Information on demographics, socioeconomic status, and lifestyle factors was collected with standardized questionnaires. The alcohol information included questions about the number of liangs (about $50 \mathrm{~g}$ ) of rice wine, corn wine, rum, beer, or liquor consumed during the preceding 12 months. Alcohol consumption was categorized into groups of grams of alcohol per day: $<25$ and $\geq 25$. Smoking status was categorized into groups of cigarettes per day: $<20$ and $\geq$ 20 . At the physical examination, several parameters, such as height, weight, and waist circumference were measured. Sitting blood pressure was measured three times with the use of a mercury sphygmomanometer after the subjects had a 5-minute rest, and the average of the three measurements was used for the level of blood pressure. Systolic blood pressure was determined by the first Korotkoff sound, and diastolic blood pressure by the fifth Korotkoff sound. Body weight, to the nearest 50 grams, was measured using a portable balance scale. Subjects were weighed without shoes and in a minimum of clothing. Height was measured, to the nearest $0.5 \mathrm{~cm}$, using a portable steel measuring device. From these two measurements body mass index (BMI, $\mathrm{kg} / \mathrm{m}^{2}$ ) was calculated.

\section{Biochemical analysis}

A venous blood sample of $8 \mathrm{~mL}$ was obtained from all subjects after at least 12 hours of fasting. A part of the sample $(3 \mathrm{~mL})$ was collected into glass tubes and used to determine serum lipid levels. Another part of the sample $(5 \mathrm{~mL})$ was transferred to tubes with anticoagulate solution $(4.80 \mathrm{~g} / \mathrm{L}$ citric acid, $14.70 \mathrm{~g} / \mathrm{L}$ glucose, and $13.20 \mathrm{~g} / \mathrm{L}$ tri-sodium citrate) and used to extract deoxyribonucleic acid (DNA). The levels of serum TC, TG, HDL-C, and LDL-C in samples were determined by enzymatic methods with commercially available kits (RANDOX Laboratories Ltd., Ardmore, Diamond Road, Crumlin Co. Antrim, United Kingdom, BT29 4QY; Daiichi Pure Chemicals Co., Ltd., Tokyo, Japan). Serum ApoA1 and ApoB levels were detected by the immunoturbidimetric immunoassay using a commercial kit (RANDOX Laboratories Ltd.). All determinations were performed with an autoanalyzer (Type 7170A; Hitachi 
Ltd., Tokyo, Japan) in the Clinical Science Experiment Center of the First Affiliated Hospital, Guangxi Medical University [39].

\section{DNA preparation and genotyping}

Total genomic DNA was isolated from peripheral blood leukocytes using the phenol-chloroform method $[8,40]$. The extracted DNA was stored at $4^{\circ} \mathrm{C}$ until analysis. Genotyping of the five SNPs was performed by polymerase chain reaction and restriction fragment length polymorphism (PCR-RFLP) $[6,8,40]$. The sequences of the forward and backward primers used for ApoA1 -75 bp G>A, ApoC3 3238C $>$ G, and ApoA5 -1131T>C were 5'CACCCGGGAGACCTGCAAGC-3' and 5'-TCTAAGCAGCCAGCTCTTGCA-3', 5'-CACTAGCCCAGAGAGAGGAGTGCC-3' and 5'-CTGAGCCCAGCCGCA CACTAA-3', and 5'-GATTGATTCAAGATGCATTTAGGAC-3' and 5'-CCCCAGGAACTGGAGCGAAA TT-3' (Sangon, Shanghai, People's Republic of China); respectively. Both ApoA5 c.553G $>\mathrm{T}$ and ApoA5 c. $457 \mathrm{G}>\mathrm{A}$ are naturally occurring restriction enzyme sites in the exon 4 of ApoA5 gene. To analyze these two polymorphic markers, exon 4 was amplified using primers 5'-TCGGCGTATGGGTGGAAGAG-3' and 5'GGCAGCAACTGAAGCCCTACAC-3'. Each reaction system of a total volume of $25 \mu \mathrm{L}$, comprised $100 \mathrm{ng}$ (3 $\mu \mathrm{L}$ ) of genomic DNA; $0.8 \mu \mathrm{L}$ of each primer (20 pmo1); $4 \mu \mathrm{L}$ of $10 \times$ buffer solution; $3 \mu \mathrm{L}$ dNTP; and $0.4 \mu \mathrm{L}(1$ U) Taq polymerase. For the amplification, initial denaturation at $95^{\circ} \mathrm{C}$ for 5 min was followed by 30 cycles of denaturation at $95^{\circ} \mathrm{C}$ for $15 \mathrm{~s}$, annealing at $61^{\circ} \mathrm{C}$ for 1 min, and extension at $72^{\circ} \mathrm{C}$ for $1 \mathrm{~min}$, with final extension at $72^{\circ} \mathrm{C}$ for $7 \mathrm{~min}$. Each restriction enzyme reaction was performed with $15 \mu \mathrm{L}$ of amplified DNA; $2 \mu \mathrm{L}$ of $10 \times$ buffer solution; and restriction ezyme $(0.15 \mu \mathrm{L}$ or 1.5 U MspI for ApoA1 -75bp G>A, 0.2 U Sst I for ApoC3 3238C $>$ G, 3 U Tru1I or MseI for ApoA5 $-1131 \mathrm{~T}>\mathrm{C}, 4 \mathrm{U} M s p \mathrm{I}$ for ApoA5 c.553G>T, and $4 \mathrm{U}$ $N s b$ I or FspI for ApoA5 c.457G>A) in a total volume of $20 \mu \mathrm{L}$ digested at $37^{\circ} \mathrm{C}$ overnight. The digestive products were separated by electrophoresis on sepharose gel. The length of each digested DNA fragment was determined by comparing migration of a sample with that of standard DNA marker. Stained with ethidium bromide, the gel was visualized under ultraviolet light and photographed. Genotypes were scored by an experienced reader blinded to epidemiological data and serum lipid levels.

\section{DNA sequencing}

Twenty-eight samples (each genotype in two) detected by the PCR-RFLP were also confirmed by direct sequencing. The PCR products were purified by low melting point gel electrophoresis and phenol extraction, and then the DNA sequences were analyzed by using an $\mathrm{ABI}$ Prism 3100 (Applied Biosyatems) in Shanghai Sangon Biological Engineering Technology \& Services Co., Ltd., People's Republic of China.

\section{Diagnostic criteria}

The normal values of serum TC, TG, HDL-C, LDL-C, ApoA1, ApoB levels and the ratio of ApoA1 to ApoB in our Clinical Science Experiment Center were 3.10-5.17, 0.56-1.70, 0.91-1.81, 1.70-3.20 mmol/L, 1.00-1.76, 0.63$1.14 \mathrm{~g} / \mathrm{L}$, and 1.00-2.50; respectively [39]. The individuals with TC>5.17 mmol/L and/or TG>1.70 mmol/L were defined as hyperlipidemic [39]. Hypertension was diagnosed according to the criteria of 1999 World Health Organization-International Society of Hypertension Guidelines for the management of hypertension [41]. The diagnostic criteria of overweight and obesity were according to the Cooperative Meta-analysis Group of China Obesity Task Force. Normal weight, overweight and obesity were defined as a BMI < 24, 24-28, and $>28 \mathrm{~kg} / \mathrm{m}^{2}$; respectively [39-41].

\section{Statistical analysis}

Epidemiological data were recorded on a pre-designed form and managed with Excel software. The statistical analyses were done with the statistical software package SPSS 13.0 (SPSS Inc., Chicago, Illinois) or SAS 9.1 (SAS Institute, Inc., Cary, North Carolina, USA). Quantitative variables were expressed as mean \pm standard deviation (serum TG levels were presented as medians and interquartile ranges). Qualitative variables were expressed as percentages. Allele frequency was determined via direct counting, and the standard goodness-of-fit test was used to test the Hardy-Weinberg equilibrium. Difference in genotype distribution between the groups was obtained using the chi-square test. The difference in general characteristics between males and females was tested by the Student's unpaired $t$-test. The association of genotypes and serum lipid parameters was tested by analysis of covariance (ANCOVA). Age, BMI, blood pressure, alcohol consumption, and cigarette smoking were adjusted for the statistical analysis. Pair-wise linkage disequilibria (LD) among the five SNPs were estimated as correlation coefficients using the HelixTree program (GOLDEN Helix, Bozeman, MN, USA). For haplotype analysis, we estimated haplotype frequencies using the expectationmaximization algorithm, and determine the association between haplotypes and lipid phenotypes using trend regression analysis with the option of composite haplotype estimation implemented in HelixTree. $P$ values were further adjusted for multiple tests by a permutation test. The permutation test was conducted by changing the orders of dependant variable randomly against the genotypes (under the null hypothesis - no 
association between dependant variable and haplotypes). Then haplotype trend regression was conducted based on the same model and a $P$ value was recorded. This process was repeated 1000 times. The $P$ values of 1000 permutations were sorted in a descending manner. If the observed $P$ value is less than or equal to the $950^{\text {th }} P$ value, the association was considered statistically significant. In order to evaluate the association of serum lipid levels $(\mathrm{TC} \leq 5.17 \mathrm{mmol} / \mathrm{L}=1,>5.17 \mathrm{mmol} / \mathrm{L}=2 ; \mathrm{TG} \leq$ $1.70 \mathrm{mmol} / \mathrm{L}=1,>1.70 \mathrm{mmol} / \mathrm{L}=2 ; \mathrm{HDL}-\mathrm{C}<0.91$ $\mathrm{mmol} / \mathrm{L}=1, \geq 0.91 \mathrm{mmol} / \mathrm{L}=2 ; \mathrm{LDL}-\mathrm{C} \leq 3.20 \mathrm{mmol} / \mathrm{L}$ $=1,>3.20 \mathrm{mmol} / \mathrm{L}=2$; ApoA $1<1.00 \mathrm{~g} / \mathrm{L}=1, \geq 1.00 \mathrm{~g} /$ $\mathrm{L}=2 ;$ ApoB $\leq 1.14 \mathrm{~g} / \mathrm{L}=1,>1.14 \mathrm{~g} / \mathrm{L}=2 ;$ ApoA $1 / \mathrm{ApoB}$ $<1.00=1, \geq 1.00=2)$ with genotypes $(-75 \mathrm{bp} \mathrm{G}>\mathrm{A}$ : GG $=1, \mathrm{GA}=2, \mathrm{AA}=3 ; 3238 \mathrm{C}>\mathrm{G}: \mathrm{CC}=1, \mathrm{CG}=2, \mathrm{GG}=$ $3 ;-1131 \mathrm{~T}>\mathrm{C}: \mathrm{TT}=1, \mathrm{TC}=2, \mathrm{CC}=3 ;$ c.553G $>\mathrm{T}: \mathrm{GG}=$ $1, \mathrm{GT}=2$; c.457G $>\mathrm{A}: \mathrm{GG}=1, \mathrm{GA} / \mathrm{AA}=2$ ) and several environment factors, unconditional logistic regression analysis with forward stepwise modeling was also performed in the combined population of males and females, males, and females; respectively. A $P$ value of less than 0.05 was considered statistically significant.

\section{Results}

\section{Demographic and biochemical characteristics}

The demographic and biochemical characteristics of the participants according to sex are presented in Table 1. The levels of body height, weight, systolic blood pressure, diastolic blood pressure, pulse pressure; the prevalence of hypertension; and the percentages of subjects who consumed alcohol or smoked cigarettes were higher in males than in females $(P<0.05-0.001)$, whereas the levels of BMI, HDL-C and ApoA1 were lower in males than in females $(P<0.05$ for all). There was no significant difference in the levels of age, TC, TG, LDL-C, ApoB, and the ratio of ApoA1 to ApoB $(P>0.05$ for all).

\section{Results of electrophoresis and genotyping}

After the genomic DNA of the samples was amplified by PCR and imaged by agarose gel electrophoresis for

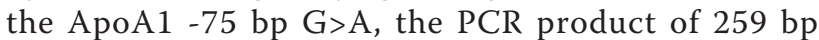
nucleotide sequences could be seen in the samples. The GG, GA and AA genotypes are shown in Figure 1A. The PCR product of the ApoC3 3238C >G was 596

Table 1 Comparison of general characteristics and serum lipid levels of the participants according to sex

\begin{tabular}{|c|c|c|c|c|}
\hline Parameter & $\begin{array}{c}\text { Male } \\
(n=492)\end{array}$ & $\begin{array}{c}\text { Female } \\
(n=538)\end{array}$ & $t\left(\chi^{2}\right)$ & $P$ \\
\hline Age (years) & $43.65 \pm 18.35$ & $42.98 \pm 17.07$ & 0.607 & 0.544 \\
\hline Height (cm) & $156.69 \pm 10.25$ & $147.88 \pm 6.36$ & 16.725 & 0.000 \\
\hline Weight (kg) & $53.45 \pm 8.99$ & $48.17 \pm 7.51$ & 10.260 & 0.000 \\
\hline Body mass index $\left(\mathrm{kg} / \mathrm{m}^{2}\right)$ & $21.64 \pm 2.31$ & $21.96 \pm 2.76$ & -2.008 & 0.045 \\
\hline$>24 \mathrm{~kg} / \mathrm{m}^{2}[\mathrm{n}(\%)]$ & $58(11.79)$ & $98(18.22)$ & 8.260 & 0.004 \\
\hline Systolic blood pressure (mmHg) & $125.28 \pm 17.14$ & $120.55 \pm 14.80$ & 4.751 & 0.000 \\
\hline Diastolic blood pressure $(\mathrm{mmHg})$ & $77.61 \pm 10.46$ & $74.45 \pm 9.24$ & 5.147 & 0.000 \\
\hline Pulse pressure $(\mathrm{mmHg})$ & $47.70 \pm 12.60$ & $46.14 \pm 11.35$ & 2.090 & 0.037 \\
\hline Hypertensive prevalence [n (\%)] & 96(19.51) & $52(9.67)$ & 20.251 & 0.000 \\
\hline \multicolumn{5}{|l|}{ Cigarette smoking [n (\%)] } \\
\hline Nonsmoker & 200(40.6) & 506(94.0) & & \\
\hline$<20$ cigarettes/day & 138(28.1) & 30(5.6) & & \\
\hline$\geq 20$ cigarettes/day & 154(31.3) & $2(0.4)$ & 348.801 & 0.000 \\
\hline \multicolumn{5}{|l|}{ Alcohol consumption [n (\%)] } \\
\hline Nondrinker & 186(37.8) & $330(61.4)$ & & \\
\hline$<25 \mathrm{~g} /$ day & 192(39.0) & 204(37.9) & & \\
\hline$\geq 25 \mathrm{~g} /$ day & 114(23.2) & $4(0.7)$ & 141.320 & 0.000 \\
\hline Total cholesterol (mmol/L) & $4.61 \pm 1.01$ & $4.69 \pm 0.90$ & -1.344 & 0.179 \\
\hline Triglycerides (mmol/L) & $1.00(0.58)$ & $0.97(0.60)$ & 0.206 & 0.837 \\
\hline $\mathrm{HDL}-\mathrm{C}(\mathrm{mmol} / \mathrm{L})$ & $2.03 \pm 0.49$ & $2.09 \pm 0.46$ & -2.027 & 0.043 \\
\hline LDL-C (mmol/L) & $2.36 \pm 0.74$ & $2.44 \pm 0.66$ & -1.834 & 0.067 \\
\hline Apolipoprotein (Apo) A1 (g/L) & $1.43 \pm 0.17$ & $1.45 \pm 0.13$ & -2.131 & 0.033 \\
\hline ApoB $(g / L)$ & $0.90 \pm 0.22$ & $0.92 \pm 0.20$ & -1.528 & 0.127 \\
\hline ApoA1/ApoB & $1.71 \pm 0.58$ & $1.66 \pm 0.44$ & 1.567 & 0.118 \\
\hline
\end{tabular}

HDL-C, high-density lipoprotein cholesterol; LDL-C, low-density lipoprotein cholesterol. The value of triglyceride was presented as median (interquartile range). The difference between the two sexes was determined by the Wilcoxon-Mann-Whitney test. 

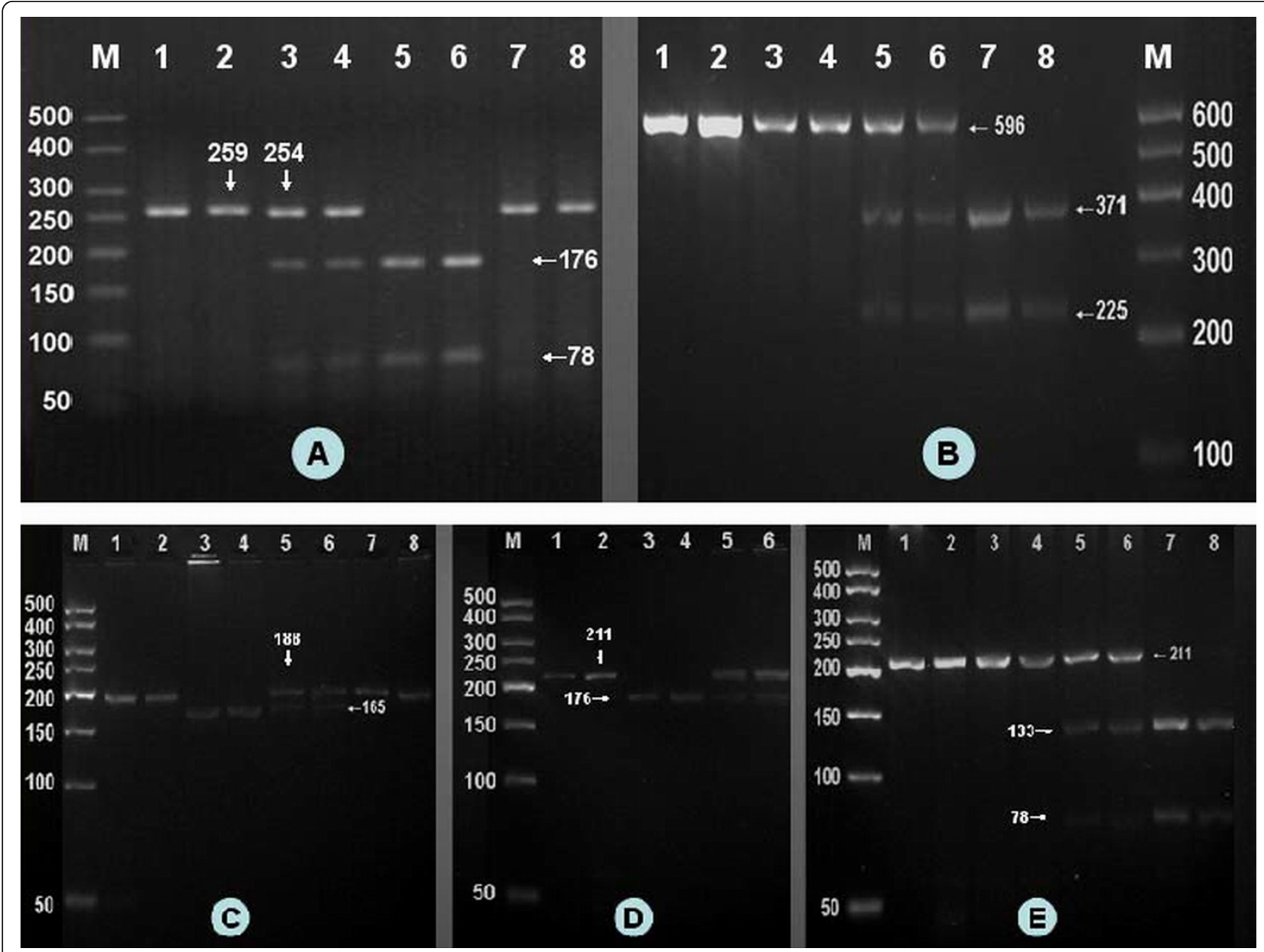

Figure 1 Genotyping of the ApoA1/C3/A5 gene polymorphisms. (A) ApoA1 -75 bp G>A. Lane M, 50 bp marker ladder; lanes 1 and 2, the PCR products of the samples (259 bp); lanes 3 and 4, GA genotype (254-, 176- and 78-bp); lanes 5 and 6, GG genotype (176- and 78-bp); and lanes 7 and 8, AA genotype (254 bp). (B) ApoC3 3238C>G. Lane M, 100 bp marker ladder; lanes 1 and 2, the PCR products of the samples (596 bp); lanes 3 and 4, CC genotype (596 bp); lanes 5 and 6, CG genotype (596-, 371- and 225-bp); and lanes 7 and 8, GG genotype (371- and 225bp). (C) ApoA5 -1131T>C. Lanes 1 and 2, the PCR products of the samples (188 bp); lanes 3 and 4, TT genotype (165- and 23-bp); lanes 5 and 6, TC genotype (188-, 165- and 23-bp); and Lanes 7 and 8, CC genotype (188 bp). The 23 bp fragment was invisible in the gel owing to its fast migration speed. (D) ApoA5 c.553G>T. Lane M, 50 bp marker ladder; lanes 1 and 2, the PCR products of the samples (211 bp); lanes 3 and 4, GG genotype (176- and 35-bp); lanes 5 and 6, GT genotype (211-, 176- and 35-bp). TT genotype was not detected in both sexes. The 35 bp fragment was invisible in the gel owing to its fast migration speed. (E) ApoA5 c.457G>A. Lanes 1 and 2, the PCR products of the samples (211 bp); lanes 3 and 4, GG genotype (211 bp); lanes 5 and 6, GA genotype (211-, 133- and 78-bp); and lanes 7 and 8, AA genotype (133- and 78-bp).

bp nucleotide sequences. The CC, CG and GG genotypes are shown in Figure 1B. The PCR product of the ApoA5 -1131T $>$ C was 188 bp nucleotide sequences. The TT, TC and CC genotypes are shown in Figure 1C. The PCR product of the ApoA5 c.553G $>$ T was 211 bp nucleotide sequences. The GG and GT genotypes are shown in Figure 1D. The TT genotype was not detected in our study population. The PCR product of the ApoA5 c.457G>A was 211 bp nucleotide sequences. The GG, GA and AA genotypes are shown in Figure 1E.

\section{Results of sequencing}

The results were shown as GG, GA and AA genotypes of the ApoA1 -75bp G>A; CC, CG and GG genotypes of the ApoC3 3238C >G; TT, TC and CC genotypes of the ApoA5 -1131T>C; GG and GT genotypes of the ApoA5 c.553G>T; and GG, GA and AA genotypes of the ApoA5 c.457G>A by PCR-RFLP, the genotypes were also confirmed by sequencing (Figure 2); respectively. We have deposited the raw data at Genbank's Gene Expression Omnibus (GEO) database under accession number GRP3220754. 

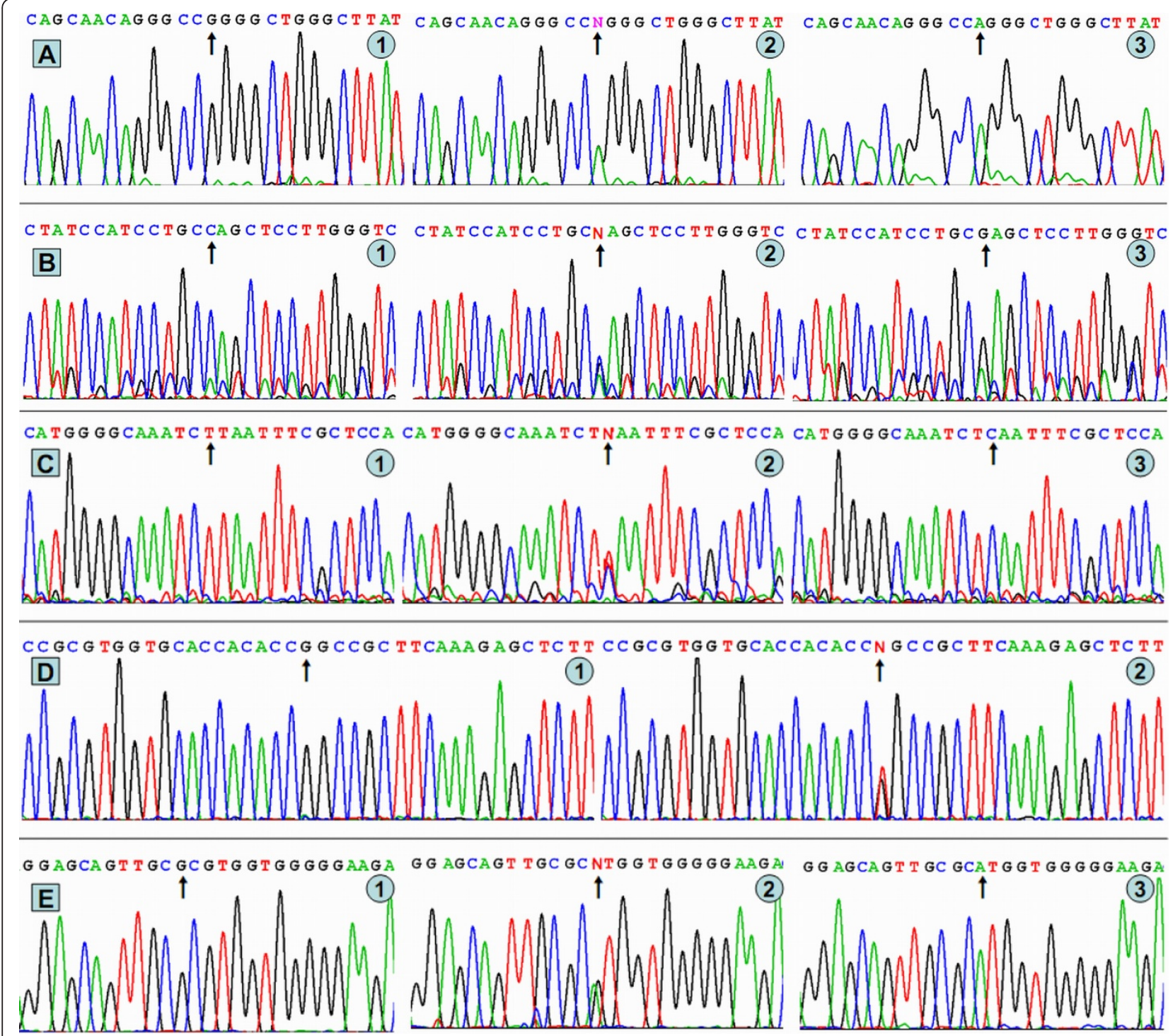

Figure 2 A part of the nucleotide sequences of the ApoA1/C3/A5 gene polymorphisms. (A) ApoA1 -75 bp G>A: (1) GG genotype, (2) GA genotype, (3) AA genotype. (B) ApoC3 3238C>G: (1) CC genotype, (2) CG genotype, (3) GG genotype (C) ApoA5 -1131T>C: (1) TT genotype, (2) TC genotype, (3) CC genotype; (D) ApoA5 c.553G>T: (1) GG genotype, (2) GT genotype; (E) ApoA5 c.457G>A: (1) GG genotype, (2) GA genotype, (3) AA genotype.

\section{Genotypic and allelic frequencies}

The genotypic frequencies of each of the five loci were all in Hardy-Weinberg equilibrium (ApoA1 -75bp G>A: $\chi^{2}=3.492, P=0.062$; ApoC3 3238C $>$ G: $\chi^{2}=0.108, P=$ 0.743 ; ApoA5 -1131T $>C: \chi^{2}=1.524, P=0.217$; ApoA5 c.553G >T: $\chi^{2}=1.200, P=0.273$; ApoA5 c. $457 \mathrm{G}>\mathrm{A}: \chi^{2}$ $=2.470, P=0.116$; respectively). For five SNPs, ApoA1 -75bp G>A was in LD with ApoC3 3238C $>$ G $(P<$ $0.001)$, ApoA5 -1131T>C $(P<0.04)$, ApoA5 c.553G $>\mathrm{T}$ $(P<0.001)$, and ApoA5 c.457G $>$ A $(P<0.002)$. ApoC3 $3238 \mathrm{C}>\mathrm{G}$ was in LD with ApoA5 $-1131 \mathrm{~T}>\mathrm{C}(P<0.001)$. ApoA5 $-1131 \mathrm{~T}>\mathrm{C}$ was in LD with ApoA5 c.553G $>\mathrm{T}(P$ $<0.001)$ and ApoA5 c.457G>A $(P<0.001)$. There was no LD between ApoC3 3238C $>\mathrm{G}$ and ApoA5 c.553G $>\mathrm{T}$ or ApoA5 c.457G>A; and between ApoA5 c.553G>T and ApoA5 c.457G $>$ A $(P>0.05$ for all; Figure 3). The frequency of ApoC3 3238C and 3238G alleles was 70.7\% and $29.3 \%$ in males, and $64.7 \%$ and $35.3 \%$ in females $(P$ $<0.01$ ); respectively. The frequency of CC, CG and GG genotypes was $51.2 \%, 39.0 \%$ and $9.8 \%$ in males, and $40.2 \%, 49.0 \%$ and $10.8 \%$ in females $(P<0.01)$; respectively. There was no difference in the genotypic and allelic frequencies of the ApoA1 -75bp G>A, ApoA5 $-1131 \mathrm{~T}>\mathrm{C}$, ApoA5 c.553G $>\mathrm{T}$, and ApoA5 c.457G $>\mathrm{A}$ between the males and females $(P>0.05$ for all; Table 2). 


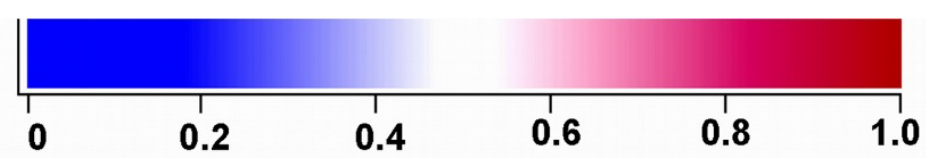

\section{Linkage disequilibria (LD) correlation coefficient}
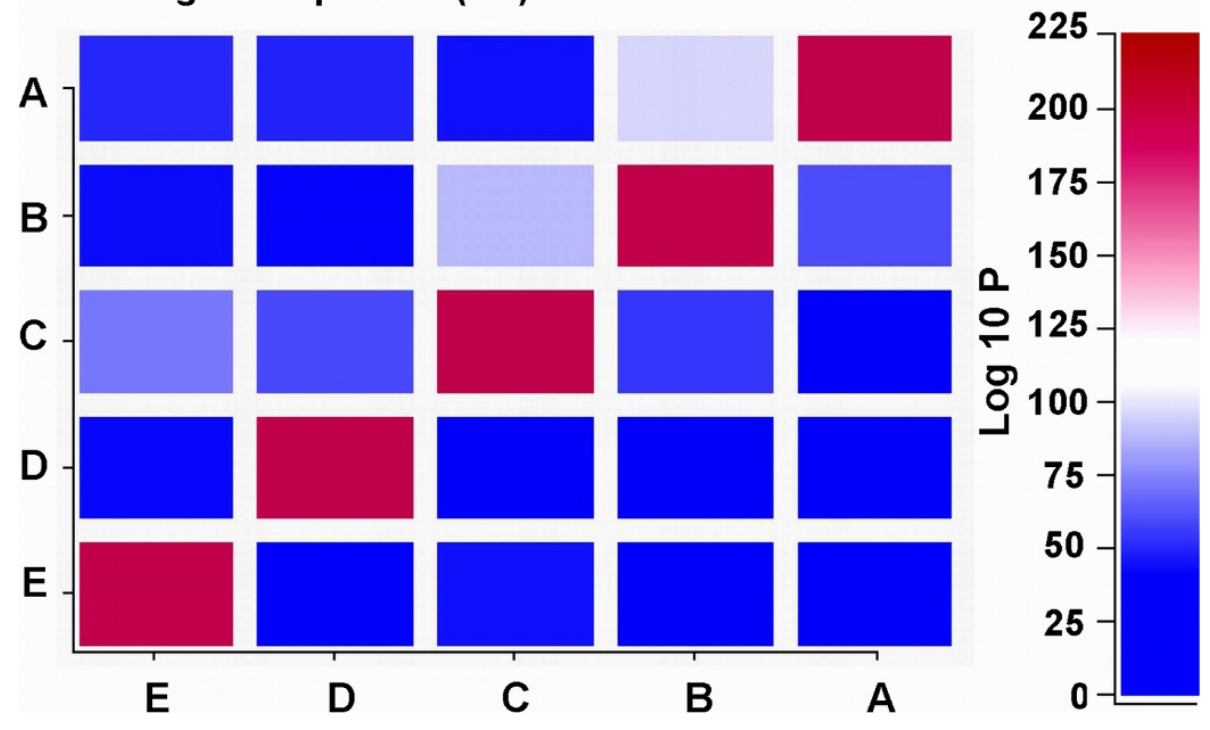

Figure 3 The linkage disequilibria (LD) among the five SNPs. (A) ApoA1 -75bp G>A, (B) ApoC3 3238C>G, (C) ApoA5 -1131T>C, (D) ApoA5 c.457G $>A$, and (E) ApoA5 c.553G>T. ApoA1 -75bp G>A was in LD with ApoC3 3238C $>$ G (LD correlation coefficient $r=0.410, P<0.001)$, ApoA5 $-1131 \mathrm{~T}>C(r=0.064, P<0.04)$, ApoA5 C.553G $>\mathrm{T}(r=0.106, P<0.001)$, and ApoA5 c.457G $>\mathrm{A}(r=0.096, P<0.002)$. ApoC3 3238C $>\mathrm{G}$ was in LD with ApoA5 -1131T>C ( $r=0.359, P<0.001)$. ApoA5 -1131T>C was in LD with ApoA5 c.553G $>\mathrm{T}(r=0.245, P<0.001)$ and ApoA5 $c .457 \mathrm{G}>\mathrm{A}(r=$ $0.165, P<0.001)$. There was no LD between ApoC3 3238C $>\mathrm{G}$ and ApoA5 C.553G $>\mathrm{T}(r=0.059, P=0.059)$ or ApoA5 $c .457 \mathrm{G}>\mathrm{A}(r=0.044, P=$ 0.155); and between ApoA5 c.553G>T and ApoA5 c.457G>A ( $r=0.048, P=0.126)$.

Table 2 The genotypic and allelic frequencies of ApoA1/C3/A5 gene polymorphisms between males and females

\begin{tabular}{|c|c|c|c|c|c|c|c|}
\hline \multirow[t]{2}{*}{ SNP } & \multirow[t]{2}{*}{ Group } & \multirow[t]{2}{*}{$\mathrm{n}$} & \multicolumn{3}{|c|}{ Genotype [n (\%)] } & \multicolumn{2}{|c|}{ Allele [n (\%)] } \\
\hline & & & AA & $A B$ & BB & A & B \\
\hline ApoA1 -75bp G>A & Male & 492 & 192(39.0) & $242(49.2)$ & $58(11.8)$ & $626(63.6)$ & $358(36.4)$ \\
\hline \multirow[t]{3}{*}{ (rs1799837) } & Female & 538 & 210(39.0) & 264(49.1) & 64(11.9) & 684(63.6) & $392(36.4)$ \\
\hline & $\chi^{2}$ & - & \multicolumn{3}{|c|}{0.003} & \multicolumn{2}{|c|}{0.001} \\
\hline & $P$ & - & \multicolumn{3}{|c|}{0.998} & \multicolumn{2}{|c|}{0.982} \\
\hline ApoC3 3238C>G & Male & 492 & 252(51.2) & 192(39.0) & $48(9.8)$ & $696(70.7)$ & 288(29.3) \\
\hline \multirow[t]{3}{*}{ 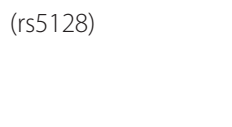 } & Female & 538 & $216(40.2)$ & 264(49.0) & $58(10.8)$ & $696(64.7)$ & $380(35.3)$ \\
\hline & $\chi^{2}$ & - & \multicolumn{3}{|c|}{13.053} & \multicolumn{2}{|c|}{8.579} \\
\hline & P & - & \multicolumn{3}{|c|}{0.002} & \multicolumn{2}{|c|}{0.003} \\
\hline ApoA5 -1131T>C & Male & 492 & $268(54.4)$ & 178(36.2) & $46(9.4)$ & 714(72.6) & $270(27.4)$ \\
\hline \multirow[t]{3}{*}{ (rs662799) } & Female & 538 & 266(49.4) & $226(42.0)$ & $46(8.6)$ & 758(70.4) & 318(29.6) \\
\hline & $\chi^{2}$ & - & \multicolumn{3}{|c|}{3.663} & \multicolumn{2}{|c|}{1.127} \\
\hline & P & - & \multicolumn{3}{|c|}{0.160} & \multicolumn{2}{|c|}{0.288} \\
\hline ApoA5 c.553G>T & Male & 492 & 466(94.7) & $26(5.3)$ & 0 & 958(97.4) & $26(2.6)$ \\
\hline \multirow[t]{3}{*}{ (rs2075291) } & Female & 538 & $496(92.2)$ & $42(7.8)$ & 0 & 1034(96.1) & $42(3.9)$ \\
\hline & $\chi^{2}$ & - & \multicolumn{3}{|c|}{2.651} & \multicolumn{2}{|c|}{2.561} \\
\hline & P & - & \multicolumn{3}{|c|}{0.103} & \multicolumn{2}{|c|}{0.109} \\
\hline ApoA5 c.457G >A & Male & 492 & $424(86.2)$ & $64(13.0)$ & $4(0.8)$ & 912(92.7) & $72(7.3)$ \\
\hline \multirow[t]{3}{*}{ (rs3135507) } & Female & 538 & 484(90.0) & $48(8.9)$ & $6(1.1)$ & 1016(94.4) & $60(5.6)$ \\
\hline & $\chi^{2}$ & - & \multicolumn{3}{|c|}{4.605} & \multicolumn{2}{|c|}{2.597} \\
\hline & $P$ & - & \multicolumn{3}{|c|}{0.100} & \multicolumn{2}{|c|}{0.107} \\
\hline
\end{tabular}

Allele A: -75bp G, 3238C, -1131T, c.553G or c.457G; Allele B: -75bp A, 3238G, -1131C, c.553T or c.457A; Genotype AA: -75bp GG, 3238CC, -1131T, c.553GG or c.457GG; Genotype AB: -75bp GA, 3238CG, -1131TC, c.553GT or c.457GA; Genotype BB: -75bp AA, 3238GG, -1131CC, c.553TT or c.457AA 


\section{Genotypes and serum lipid levels}

As shown in Table 3, the levels of TG in males were different among the GG, GA and AA genotypes of the ApoA1 -75bp $\mathrm{G}>\mathrm{A}(P<0.003)$, whereas the levels of HDL-C and the ratio of ApoA1 to ApoB in females were different among the three genotypes $(P<0.05$ and $P<0.01$; respectively).

The levels of HDL-C in males were different among the CC, CG and GG genotypes of the ApoC3 3238C>G $(P<0.05)$, whereas the levels of TG in females were different among the three genotypes $(P<0.01)$.

The levels of TC, TG, LDL-C, ApoB, and the ratio of ApoA1 to ApoB in males were different among the TT, TC and CC genotypes of the ApoA5 -1131T $>C(P<$ 0.05-0.001), whereas the levels of TG in females were different among the three genotypes $(P<0.001)$.

The levels of TG and HDL-C in males were different between the GG and GT genotypes of the ApoA5 c.553G $>$ T $(P<0.01$ for each), whereas the levels of HDL-C in females were different between the two genotypes $(P<0.05)$.

The levels of HDL-C and ApoA1 in males were different between the GG and GA/AA genotypes of the ApoA5 c.457G $>$ A $(P<0.001$ for each), whereas the levels of TC, LDL-C, ApoB, and the ratio of ApoA1 to $A p o B$ in females were different between the GG and GA/AA genotypes $(P<0.05-0.01)$.

\section{Haplotypes and serum lipid levels}

To examine the combined effect of five variants (in the order of ApoA5 c.553G>T, ApoA5 c.457G >A, ApoA5 $-1131 \mathrm{~T}>\mathrm{C}$, ApoC3 3238C >G, ApoA1 -75bp G>A) in the cluster, we conducted haplotype analysis with these SNPs on the serum lipid traits (Table 4). There were 11 haplotypes with a frequency $>1 \%$ identified in the cluster in our population. To increase the statistical power of analysis, we combined five haplotypes with frequencies less than $4 \%$ into one group, called "rare-hap", which gives a pooled frequency of $9 \%$. The frequencies of other six haplotypes are listed in Table 4 with G-G-TC-G and G-G-T-C-A each accounting for 26\% haplotype of the population; respectively. At the global level, the haplotypes comprised of all five SNPs were significantly associated with all seven lipid traits (Table 4) with $P$ values ranging from $1.56 \times 10^{-6}$ to 0.001 before or 0.001 to 0.003 after correcting for multiple testing by permuation test. In particular, haplotype G-G-C-C-A (6\%) and G-A-T-C-G (4\%) showed consistent association with TC, LDL-C, ApoA1, ApoB, and the ratio of ApoA1 to ApoB. In addition, carriers of haplotype G-GT-C-G (26\%) had increased serum concentration of HDL-C and ApoA1, whereas carriers of G-G-C-G-G (15\%) had high concentrations of TC, TG, and ApoB.
We also found that haplotypes with five SNPs explain much more serum lipid variation than any single SNP alone, especially for TG (4.4\% for haplotype vs $2.4 \%$ for $-1131 \mathrm{~T}>\mathrm{C}$ max based on R-square) and HDL-C (5.1\% for haplotype vs $0.9 \%$ for c.553G $>\mathrm{T}$ based on R-square).

\section{Correlation between genotypes and several environment factors and serum lipid levels}

For males, multivariate logistic regression analysis showed that the levels of TC were correlated with ApoA5 -1131T $>C$ genotypes; the levels of TG were correlated with ApoA1 -75bp G>A and ApoA5 c.553G>T genotypes, and ApoA5 c.457 G>A, ApoA5 -1131T>C and ApoC3 3238C >G alleles; the levels of LDL-C were correlated with ApoC3 3238C $>$ G genotypes; the levels of ApoB were correlated with ApoA5 c.457 G>A and ApoC3 $3238 \mathrm{C}>\mathrm{G}$ genotypes; the ratio of ApoA1 to ApoB was correlated with ApoA1 -75bp G>A and ApoC3 3238C $>\mathrm{G}$ alleles (Table 5).

For females, the levels of TC were correlated with ApoA5 - $1131 \mathrm{~T}>\mathrm{C}$ alleles; the levels of TG were correlated with ApoC3 3238C $>$ G genotypes, the levels of ApoB were correlated with ApoA1 -75bp G>A and ApoA5 -1131T $>$ C genotypes, ApoA1 -75bp G $>$ A, ApoC3 $3238 \mathrm{C}>\mathrm{G}$ and ApoA5 c.457 G>A alleles; the ratio of ApoA1 to ApoB was correlated with ApoA1 -75bp G>A and ApoA5 - 1131T $>$ C genotypes, and ApoA1 -75bp $\mathrm{G}>\mathrm{A}$ and ApoC3 3238C $>\mathrm{G}$ alleles (Table 5).

Serum lipid parameters were also correlated with several environment factors such as age, alcohol consumption, cigarette smoking, blood pressure, body weight, and BMI (Table 6).

\section{Discussion}

The results of the present study clearly show that the levels of serum HDL-C and ApoA1 in the general Chinese population were higher in females than in males. There was no significant difference in the levels of TC, TG, LDL-C, ApoB and the ratio of ApoA1 to ApoB between the two sexes. These findings are in good agreement with those of previous epidemiological studies $[42,43]$. Although the effects of gonadal hormones on blood lipids are considered contributing factors, the reasons for sex differences in serum lipid levels are still not fully understood. It is commonly accepted that androgens induce changes in lipid concentrations that would predispose towards CAD, whereas estrogens are held to have opposite effects $[44,45]$. However, much of the evidence for this comes from studies of changes associated with administration of synthetic gonadal steroids or with changes in gonadal function. Studies of differences in lipid metabolism in normal men and women are extremely limited. 
Table 3 The ApoA1/C3/A5 genotypes and serum lipid levels between males and females

\begin{tabular}{|c|c|c|c|c|c|c|c|c|c|}
\hline SNP & Genotype & $\mathbf{n}$ & $\begin{array}{c}\text { TC } \\
(\mathrm{mmol} / \mathrm{L})\end{array}$ & $\begin{array}{c}\text { TG } \\
(\mathrm{mmol} / \mathrm{L})\end{array}$ & $\begin{array}{c}\mathrm{HDL}-\mathrm{C} \\
(\mathrm{mmol} / \mathrm{L})\end{array}$ & $\begin{array}{c}\text { LDL-C } \\
(\mathrm{mmol} / \mathrm{L})\end{array}$ & $\begin{array}{c}\text { ApoA1 } \\
(\mathrm{g} / \mathrm{L})\end{array}$ & $\begin{array}{c}\text { ApoB } \\
(\mathrm{g} / \mathrm{L})\end{array}$ & $\begin{array}{c}\text { ApoA1/ } \\
\text { ApoB }\end{array}$ \\
\hline ApoA1 -75bp G>A & Male & & & & & & & & \\
\hline \multirow[t]{11}{*}{ (rs1799837) } & GG & 192 & $4.57 \pm 1.06$ & $0.92(0.46)$ & $2.02 \pm 0.46$ & $2.40 \pm 0.72$ & $1.42 \pm 0.18$ & $0.90 \pm 0.22$ & $1.67 \pm 0.44$ \\
\hline & GA & 242 & $4.67 \pm 1.03$ & $1.05(0.70)$ & $2.06 \pm 0.54$ & $2.32 \pm 0.79$ & $1.45 \pm 0.16$ & $0.89 \pm 0.23$ & $1.73 \pm 0.52$ \\
\hline & AA & 58 & $4.51 \pm 0.66$ & $0.78(0.54)$ & $1.94 \pm 0.37$ & $2.43 \pm 0.53$ & $1.41 \pm 0.14$ & $0.89 \pm 0.21$ & $1.77 \pm 1.04$ \\
\hline & $F$ & - & 0.867 & 11.673 & 1.458 & 0.894 & 2.408 & 0.117 & 0.914 \\
\hline & $P$ & - & 0.421 & 0.003 & 0.234 & 0.410 & 0.091 & 0.890 & 0.402 \\
\hline & Female & & & & & & & & \\
\hline & GG & 210 & $4.73 \pm 0.86$ & $0.99(0.62)$ & $2.15 \pm 0.51$ & $2.39 \pm 0.65$ & $1.46 \pm 0.13$ & $0.90 \pm 0.21$ & $1.74 \pm 0.56$ \\
\hline & GA & 264 & $4.68 \pm 0.92$ & $0.96(0.59)$ & $2.06 \pm 0.42$ & $2.48 \pm 0.66$ & $1.45 \pm 0.14$ & $0.93 \pm 0.20$ & $1.61 \pm 0.35$ \\
\hline & AA & 64 & $4.61 \pm 0.94$ & $0.96(0.59)$ & $2.01 \pm 0.47$ & $2.43 \pm 0.69$ & $1.42 \pm 0.13$ & $0.93 \pm 0.21$ & $1.60 \pm 0.34$ \\
\hline & $F$ & - & 0.477 & 0.236 & 3.273 & 1.094 & 2.153 & 1.369 & 5.689 \\
\hline & $P$ & - & 0.621 & 0.889 & 0.039 & 0.336 & 0.117 & 0.255 & 0.004 \\
\hline ApoC3 3238C>G & Male & & & & & & & & \\
\hline \multirow[t]{11}{*}{$($ rs5128) } & $C C$ & 252 & $4.57 \pm 0.96$ & $0.93(0.65)$ & $1.97 \pm 0.45$ & $2.34 \pm 0.76$ & $1.42 \pm 0.15$ & $0.88 \pm 0.23$ & $1.75 \pm 0.69$ \\
\hline & $C G$ & 192 & $4.61 \pm 1.02$ & $1.00(0.50)$ & $2.11 \pm 0.57^{b}$ & $2.35 \pm 0.66$ & $1.44 \pm 0.19$ & $0.89 \pm 0.20$ & $1.68 \pm 0.42$ \\
\hline & GG & 48 & $4.85 \pm 1.21$ & $1.02(0.60)$ & $2.07 \pm 0.36$ & $2.57 \pm 0.90$ & $1.45 \pm 0.15$ & $0.96 \pm 0.27$ & $1.64 \pm 0.46$ \\
\hline & $F$ & - & 1.551 & 2.954 & 4.528 & 2.036 & 1.138 & 2.601 & 1.213 \\
\hline & $P$ & - & 0.213 & 0.228 & 0.011 & 0.132 & 0.321 & 0.075 & 0.298 \\
\hline & Female & & & & & & & & \\
\hline & CC & 216 & $4.65 \pm 0.80$ & $0.92(0.60)$ & $2.08 \pm 0.42$ & $2.45 \pm 0.62$ & $1.45 \pm 0.12$ & $0.91 \pm 0.17$ & $1.64 \pm 0.31$ \\
\hline & $C G$ & 264 & $4.67 \pm 0.98$ & $0.98(0.64)$ & $2.10 \pm 0.48$ & $2.41 \pm 0.68$ & $1.44 \pm 0.14$ & $0.92 \pm 0.21$ & $1.67 \pm 0.46$ \\
\hline & GG & 58 & $4.93 \pm 0.87$ & $1.02(1.00)$ & $2.05 \pm 0.53$ & $2.56 \pm 0.72$ & $1.45 \pm 0.12$ & $0.95 \pm 0.25$ & $1.68 \pm 0.73$ \\
\hline & $F$ & - & 2.342 & 15.113 & 0.314 & 1.249 & 0.403 & 0.920 & 0.339 \\
\hline & P & - & 0.097 & 0.001 & 0.731 & 0.288 & 0.668 & 0.399 & 0.712 \\
\hline ApoA5 -1131T>C & Male & & & & & & & & \\
\hline \multirow[t]{11}{*}{ (rs662799) } & $\pi$ & 268 & $4.56 \pm 1.01$ & $0.91(0.53)$ & $2.04 \pm 0.48$ & $2.33 \pm 0.76$ & $1.43 \pm 0.15$ & $0.88 \pm 0.22$ & $1.76 \pm 0.68$ \\
\hline & $\mathrm{TC}$ & 178 & $4.58 \pm 1.01$ & $1.03(0.66)$ & $1.99 \pm 0.49$ & $2.34 \pm 0.70$ & $1.42 \pm 0.19$ & $0.90 \pm 0.22$ & $1.67 \pm 0.42$ \\
\hline & $\mathrm{CC}$ & 46 & $5.08 \pm 0.90$ & $1.14(0.72)$ & $2.15 \pm 0.56$ & $2.66 \pm 0.67$ & $1.47 \pm 0.12$ & $0.99 \pm 0.22$ & $1.57 \pm 0.42$ \\
\hline & $F$ & - & 7.637 & 13.443 & 0.535 & 4.492 & 0.135 & 8.091 & 7.797 \\
\hline & $P$ & - & 0.001 & 0.001 & 0.586 & 0.012 & 0.873 & 0.000 & 0.000 \\
\hline & Female & & & & & & & & \\
\hline & $\pi$ & 266 & $4.60 \pm 0.84$ & $0.89(0.58)$ & $2.09 \pm 0.42$ & $2.39 \pm 0.66$ & $1.44 \pm 0.13$ & $0.90 \pm 0.19$ & $1.69 \pm 0.38$ \\
\hline & $\mathrm{TC}$ & 226 & $4.77 \pm 0.99$ & $1.04(0.64)$ & $2.10 \pm 0.52$ & $2.49 \pm 0.67$ & $1.45 \pm 0.14$ & $0.95 \pm 0.20$ & $1.61 \pm 0.41$ \\
\hline & $\mathrm{CC}$ & 46 & $4.79 \pm 0.77$ & $1.01(1.04)$ & $2.03 \pm 0.45$ & $2.48 \pm 0.64$ & $1.45 \pm 0.12$ & $0.93 \pm 0.25$ & $1.74 \pm 0.78$ \\
\hline & $F$ & - & 1.662 & 16.015 & 0.272 & 1.233 & 0.333 & 2.154 & 0.278 \\
\hline & P & - & 0.191 & 0.000 & 0.762 & 0.292 & 0.717 & 0.117 & 0.758 \\
\hline ApoA5 c.553G>T & Male & & & & & & & & \\
\hline \multirow[t]{9}{*}{ (rs2075291) } & GG & 466 & $4.61 \pm 1.02$ & $0.93(0.56)$ & $2.05 \pm 0.50$ & $2.36 \pm 0.74$ & $1.43 \pm 0.16$ & $0.89 \pm 0.22$ & $1.72 \pm 0.58$ \\
\hline & GT & 26 & $4.64 \pm 0.87$ & $1.63(1.39)$ & $1.74 \pm 0.33$ & $2.38 \pm 0.75$ & $1.39 \pm 0.18$ & $0.96 \pm 0.27$ & $1.62 \pm 0.67$ \\
\hline & $F$ & - & 0.147 & 4.108 & 3.122 & 0.134 & 1.232 & 1.559 & 0.848 \\
\hline & $P$ & - & 0.883 & 0.000 & 0.002 & 0.893 & 0.218 & 0.120 & 0.397 \\
\hline & Female & & & & & & & & \\
\hline & GG & 496 & $4.70 \pm 0.91$ & $0.98(0.60)$ & $2.10 \pm 0.47$ & $2.44 \pm 0.66$ & $1.45 \pm 0.14$ & $0.92 \pm 0.20$ & $1.66 \pm 0.45$ \\
\hline & GT & 42 & $4.60 \pm 0.82$ & $0.97(0.74)$ & $1.97 \pm 0.33$ & $2.39 \pm 0.61$ & $1.45 \pm 0.09$ & $0.95 \pm 0.21$ & $1.60 \pm 0.35$ \\
\hline & $F$ & - & 0.689 & 0.844 & 2.359 & 0.474 & 0.000 & 0.930 & 0.843 \\
\hline & P & - & 0.491 & 0.399 & 0.018 & 0.636 & 1.000 & 0.353 & 0.399 \\
\hline ApoA5 c.457G >A & Male & & & & & & & & \\
\hline \multirow[t]{4}{*}{ (rs3135507) } & GG & 424 & $4.63 \pm 0.96$ & $1.00(0.58)$ & $2.07 \pm 0.49$ & $2.38 \pm 0.74$ & $1.44 \pm 0.15$ & $0.90 \pm 0.22$ & $1.72 \pm 0.59$ \\
\hline & GA/AA & 68 & $4.51 \pm 1.26$ & $1.01(0.63)$ & $1.79 \pm 0.43$ & $2.30 \pm 0.73$ & $1.36 \pm 0.22$ & $0.88 \pm 0.22$ & $1.64 \pm 0.50$ \\
\hline & $F$ & - & 0.913 & -0.268 & 4.445 & 0.829 & 3.795 & 0.696 & 1.059 \\
\hline & P & - & 0.362 & 0.788 & 0.000 & 0.407 & 0.000 & 0.487 & 0.290 \\
\hline
\end{tabular}


Table 3 The ApoA1/C3/A5 genotypes and serum lipid levels between males and females (Continued)

\begin{tabular}{lcccccccc}
\hline Female & & & & & & & \\
GG & 484 & $4.72 \pm 0.91$ & $0.98(0.59)$ & $2.09 \pm 0.47$ & $2.47 \pm 0.66$ & $1.45 \pm 0.14$ & $0.93 \pm 0.20$ & $1.64 \pm 0.43$ \\
GA/AA & 54 & $4.40 \pm 0.81$ & $0.94(0.45)$ & $2.06 \pm 0.38$ & $2.21 \pm 0.65$ & $1.43 \pm 0.10$ & $0.84 \pm 0.20$ & $1.82 \pm 0.52$ \\
F & - & 2.477 & 0.589 & 0.453 & 2.750 & 1.021 & 3.137 & 2.452 \\
$P$ & - & 0.014 & 0.556 & 0.651 & 0.006 & 0.309 & 0.002 & 0.014 \\
\hline
\end{tabular}

SNP, single nucleotide polymorphism; TC, total cholesterol; TG, triglyceride; HDL-C, high-density lipoprotein cholesterol; LDL-C, low-density lipoprotein cholesterol; ApoA1, apolipoprotein A1; ApoB, apolipoprotein B; ApoA1/ApoB, the ratio of apolipoprotein A1 to apolipoprotein $B$. The values of TG were presented as median (interquartile range). The difference among the genotypes was determined by the Kruskal-Wallis test or the Wilcoxon-Mann-Whitney test.

Table 4 Association between ApoA1/C3/A5 haplotypes and serum lipid levels in the combined population of males and females

\begin{tabular}{|c|c|c|c|c|c|c|c|c|c|c|}
\hline \multirow{2}{*}{$\begin{array}{l}\text { Lipid } \\
-\end{array}$} & \multirow{2}{*}{$\begin{array}{l}\text { Haplotype } \\
\text { Frequency }\end{array}$} & \multirow{2}{*}{$\begin{array}{c}\begin{array}{c}\text { G-G-T-C- } \\
\text { G }\end{array} \\
0.26\end{array}$} & \multirow{2}{*}{$\begin{array}{c}\text { G-G-T-C- } \\
\text { A } \\
0.26\end{array}$} & \multirow{2}{*}{$\begin{array}{c}\text { G-G-C-G- } \\
\mathbf{G} \\
0.15\end{array}$} & \multirow{2}{*}{$\begin{array}{c}\text { G-G-T-G- } \\
\mathbf{G} \\
0.13\end{array}$} & \multirow{2}{*}{$\begin{array}{c}\text { G-G-C-C- } \\
\text { A } \\
0.06\end{array}$} & \multirow{2}{*}{$\begin{array}{c}\text { G-A-T-C- } \\
\text { G } \\
0.04\end{array}$} & \multirow{2}{*}{$\begin{array}{c}\text { Rare Hap } \\
0.09\end{array}$} & \multicolumn{2}{|c|}{ Haplotype global association } \\
\hline & & & & & & & & & - & - \\
\hline - & $\begin{array}{l}\text { Frequency (carrier } \\
\text { vs } \\
\text { Noncarrier) }\end{array}$ & $\begin{array}{c}462 \text { vs. } \\
568\end{array}$ & $\begin{array}{c}458 \text { vs. } \\
572\end{array}$ & $\begin{array}{c}328 \text { vs. } \\
702\end{array}$ & $\begin{array}{c}236 \text { vs. } \\
794\end{array}$ & $\begin{array}{c}118 \text { vs. } \\
912\end{array}$ & 92 vs. 938 & 62 vs. 968 & $P$ & $\begin{array}{l}P \text { after } \\
\text { permutation } \\
\text { correction }\end{array}$ \\
\hline $\mathrm{TC}$ & Carrier & $\begin{array}{c}4.67 \pm \\
0.05\end{array}$ & $\begin{array}{c}4.64 \pm \\
0.05\end{array}$ & $\begin{array}{c}4.78 \pm \\
0.06\end{array}$ & $\begin{array}{c}4.71 \pm \\
0.07\end{array}$ & $\begin{array}{c}4.87 \pm \\
0.09\end{array}$ & $\begin{array}{c}4.40 \pm \\
0.10\end{array}$ & $\begin{array}{c}4.70 \pm \\
0.08\end{array}$ & & \\
\hline \multirow[t]{2}{*}{$\begin{array}{l}\text { (mmol/ } \\
\mathrm{L})\end{array}$} & Noncarrier & $\begin{array}{c}4.70 \pm \\
0.05\end{array}$ & $\begin{array}{c}4.72 \pm \\
0.05\end{array}$ & $\begin{array}{c}4.64 \pm \\
0.05\end{array}$ & $\begin{array}{c}4.68 \pm \\
0.04\end{array}$ & $\begin{array}{c}4.66 \pm \\
0.04\end{array}$ & $\begin{array}{c}4.71 \pm \\
0.04\end{array}$ & $\begin{array}{c}4.69 \pm \\
0.04\end{array}$ & & \\
\hline & $P$ & 0.514 & 0.159 & 0.024 & 0.641 & 0.021 & 0.002 & 0.882 & $\begin{array}{c}2.05 \mathrm{E}- \\
04\end{array}$ & 0.001 \\
\hline TG & Carrier & $1.10(0.07)$ & $1.23(0.07)$ & $1.38(0.08)$ & $1.20(0.09)$ & $1.27(0.12)$ & $1.73(0.13)$ & $1.15(0.16)$ & & \\
\hline \multirow{2}{*}{$\begin{array}{l}\text { (mmol/ } \\
\text { L) }\end{array}$} & Noncarrier & $1.33(0.07)$ & $1.23(0.07)$ & $1.16(0.06)$ & $1.24(0.06)$ & $1.23(0.06)$ & $1.19(0.06)$ & $1.24(0.06)$ & & \\
\hline & $P$ & 0.004 & 0.121 & $<0.001$ & 0.866 & 0.324 & 0.426 & 0.055 & $\begin{array}{c}1.50 \mathrm{E}- \\
05\end{array}$ & 0.001 \\
\hline $\mathrm{HDL}-\mathrm{C}$ & Carrier & $\begin{array}{c}2.15 \pm \\
0.03\end{array}$ & $\begin{array}{c}2.11 \pm \\
0.03\end{array}$ & $\begin{array}{c}2.14 \pm \\
0.03\end{array}$ & $\begin{array}{c}2.14 \pm \\
0.04\end{array}$ & $\begin{array}{c}2.12 \pm \\
0.05\end{array}$ & $\begin{array}{c}1.95 \pm \\
0.05\end{array}$ & $\begin{array}{c}2.02 \pm \\
0.04\end{array}$ & & \\
\hline \multirow[t]{2}{*}{$\begin{array}{l}\text { (mmol/ } \\
\mathrm{L})\end{array}$} & Noncarrier & $\begin{array}{c}2.09 \pm \\
0.03\end{array}$ & $\begin{array}{c}2.12 \pm \\
0.03\end{array}$ & $\begin{array}{c}2.10 \pm \\
0.02\end{array}$ & $\begin{array}{c}2.11 \pm \\
0.02\end{array}$ & $\begin{array}{c}2.11 \pm \\
0.02\end{array}$ & $\begin{array}{c}2.13 \pm \\
0.02\end{array}$ & $\begin{array}{c}2.13 \pm \\
0.02\end{array}$ & & \\
\hline & $P$ & 0.049 & 0.835 & 0.279 & 0.350 & 0.933 & $<0.001$ & 0.014 & $\begin{array}{c}1.56 \mathrm{E}- \\
06\end{array}$ & 0.001 \\
\hline LDL-C & Carrier & $\begin{array}{c}2.38 \pm \\
0.04\end{array}$ & $\begin{array}{c}2.37 \pm \\
0.04\end{array}$ & $\begin{array}{c}2.45 \pm \\
0.04\end{array}$ & $\begin{array}{c}2.40 \pm \\
0.05\end{array}$ & $\begin{array}{c}2.52 \pm \\
0.06\end{array}$ & $\begin{array}{c}2.14 \pm \\
0.07\end{array}$ & $\begin{array}{c}2.43 \pm \\
0.06\end{array}$ & & \\
\hline \multirow[t]{2}{*}{$\begin{array}{l}\text { (mmol/ } \\
\mathrm{L})\end{array}$} & Noncarrier & $\begin{array}{c}2.41 \pm \\
0.04\end{array}$ & $\begin{array}{c}2.42 \pm \\
0.04\end{array}$ & $\begin{array}{c}2.37 \pm \\
0.03\end{array}$ & $\begin{array}{c}2.40 \pm \\
0.03\end{array}$ & $\begin{array}{c}2.38 \pm \\
0.03\end{array}$ & $\begin{array}{c}2.42 \pm \\
0.03\end{array}$ & $\begin{array}{c}2.39 \pm \\
0.03\end{array}$ & & \\
\hline & $P$ & 0.405 & 0.311 & 0.085 & 0.978 & 0.033 & $<0.001$ & 0.561 & 0.001 & 0.003 \\
\hline ApoA1 & Carrier & $\begin{array}{c}1.48 \pm \\
0.01\end{array}$ & $\begin{array}{c}1.46 \pm \\
0.01\end{array}$ & $\begin{array}{c}1.46 \pm \\
0.01\end{array}$ & $\begin{array}{c}1.47 \pm \\
0.01\end{array}$ & $\begin{array}{c}1.49 \pm \\
0.01\end{array}$ & $\begin{array}{c}1.41 \pm \\
0.02\end{array}$ & $\begin{array}{c}1.45 \pm \\
0.01\end{array}$ & & \\
\hline \multirow[t]{2}{*}{$(g / L)$} & Noncarrier & $\begin{array}{c}1.46 \pm \\
0.01\end{array}$ & $\begin{array}{c}1.47 \pm \\
0.01\end{array}$ & $\begin{array}{c}1.47 \pm \\
0.01\end{array}$ & $\begin{array}{c}1.46 \pm \\
0.01\end{array}$ & $\begin{array}{c}1.46 \pm \\
0.01\end{array}$ & $\begin{array}{c}1.47 \pm \\
0.01\end{array}$ & $\begin{array}{c}1.47 \pm \\
0.01\end{array}$ & & \\
\hline & $P$ & 0.025 & 0.581 & 0.832 & 0.272 & 0.043 & $<0.001$ & 0.327 & $\begin{array}{c}6.97 \mathrm{E}- \\
05\end{array}$ & 0.001 \\
\hline ApoB & Carrier & $\begin{array}{c}0.90 \pm \\
0.01\end{array}$ & $\begin{array}{c}0.90 \pm \\
0.01\end{array}$ & $\begin{array}{c}0.93 \pm \\
0.01\end{array}$ & $\begin{array}{c}0.91 \pm \\
0.02\end{array}$ & $\begin{array}{c}0.96 \pm \\
0.02\end{array}$ & $\begin{array}{c}0.83 \pm \\
0.02\end{array}$ & $\begin{array}{c}0.94 \pm \\
0.02\end{array}$ & & \\
\hline \multirow[t]{2}{*}{ (g/L) } & Noncarrier & $\begin{array}{c}0.92 \pm \\
0.01\end{array}$ & $\begin{array}{c}0.92 \pm \\
0.01\end{array}$ & $\begin{array}{c}0.90 \pm \\
0.01\end{array}$ & $\begin{array}{c}0.91 \pm \\
0.01\end{array}$ & $\begin{array}{c}0.91 \pm \\
0.01\end{array}$ & $\begin{array}{c}0.92 \pm \\
0.01\end{array}$ & $\begin{array}{c}0.91 \pm \\
0.01\end{array}$ & & \\
\hline & P & 0.171 & 0.207 & 0.029 & 0.797 & 0.008 & $<0.001$ & 0.062 & $\begin{array}{c}6.85 \mathrm{E}- \\
06\end{array}$ & 0.001 \\
\hline ApoA1/ & Carrier & $\begin{array}{c}1.72 \pm \\
0.03\end{array}$ & $\begin{array}{c}1.72 \pm \\
0.03\end{array}$ & $\begin{array}{c}1.67 \pm \\
0.03\end{array}$ & $\begin{array}{c}1.70 \pm \\
0.04\end{array}$ & $\begin{array}{c}1.59 \pm \\
0.05\end{array}$ & $\begin{array}{c}1.81 \pm \\
0.06\end{array}$ & $\begin{array}{c}1.65 \pm \\
0.05\end{array}$ & & \\
\hline \multirow[t]{2}{*}{ ApoB } & Noncarrier & $\begin{array}{c}1.69 \pm \\
0.03\end{array}$ & $\begin{array}{c}1.69 \pm \\
0.03\end{array}$ & $\begin{array}{c}1.72 \pm \\
0.03\end{array}$ & $\begin{array}{c}1.70 \pm \\
0.02\end{array}$ & $\begin{array}{c}1.72 \pm \\
0.02\end{array}$ & $\begin{array}{c}1.69 \pm \\
0.02\end{array}$ & $\begin{array}{c}1.71 \pm \\
0.02\end{array}$ & & \\
\hline & $P$ & 0.357 & 0.211 & 0.115 & 0.975 & 0.011 & 0.031 & 0.173 & 0.001 & 0.003 \\
\hline
\end{tabular}

TC, total cholesterol; TG, triglyceride; HDL-C, high-density lipoprotein cholesterol; LDL-C, low-density lipoprotein cholesterol; ApoA1, apolipoprotein A1; ApoB, apolipoprotein B; ApoA1/ApoB, the ratio of apolipoprotein A1 to apolipoprotein B 
Table 5 Correlation between serum lipid parameters and alleles/genotypes in the males and females

\begin{tabular}{|c|c|c|c|c|c|}
\hline Lipid parameter & Risk factor & $\chi^{2}$ & $P$ & Odds ratio & $95 \% \mathrm{Cl}$ \\
\hline \multicolumn{6}{|l|}{ Male plus female } \\
\hline $\mathrm{TC}$ & ApoA5 -1131T>C allele & 12.284 & 0.000 & 1.704 & $1.265-2.295$ \\
\hline \multirow[t]{4}{*}{ TG } & ApoA5 c.553G>T genotype & 5.986 & 0.014 & 2.293 & $1.180-4.460$ \\
\hline & ApoA5 c.457 G>A allele & 7.713 & 0.005 & 2.243 & $1.268-3.968$ \\
\hline & ApoA5 -1131T>C allele & 6.647 & 0.010 & 1.534 & $1.108-2.123$ \\
\hline & ApoA1 -75bp G>A genotype & 5.337 & 0.021 & 0.345 & $0.140-0.851$ \\
\hline $\mathrm{HDL}-\mathrm{C}$ & ApoA5 c.457 G>A allele & 7.595 & 0.006 & 16.571 & $2.250-12.048$ \\
\hline LDL-C & ApoC3 3238C>G genotype & 12.001 & 0.001 & 2.834 & $1.572-5.111$ \\
\hline ApoA1 & ApoA5 c.553G>T genotype & 4.978 & 0.026 & 11.297 & $1.343-5.052$ \\
\hline ApoB & ApoC3 3238C>G genotype & 13.034 & 0.000 & 1.514 & $1.209-1.897$ \\
\hline \multicolumn{6}{|l|}{ Male } \\
\hline TC & ApoA5 -1131T>C genotype & 4.910 & 0.027 & 1.428 & $1.042-1.957$ \\
\hline \multirow[t]{5}{*}{ TG } & ApoA5 c.553G>T genotype & 17.322 & 0.000 & 7.990 & $3.003-21.260$ \\
\hline & ApoA5 c.457 G>A allele & 4.097 & 0.043 & 2.263 & $1.026-4.989$ \\
\hline & ApoA5 -1131T>C allele & 7.400 & 0.007 & 2.590 & $1.305-5.143$ \\
\hline & ApoC3 3238C>G allele & 3.904 & 0.048 & 0.503 & $0.254-0.995$ \\
\hline & ApoA1 -75bp G>A genotype & 5.372 & 0.020 & 0.240 & $0.072-0.802$ \\
\hline LDL-C & ApoC3 3238C>G genotype & 8.307 & 0.004 & 1.886 & $1.225-2.904$ \\
\hline \multirow[t]{2}{*}{ ApoB } & ApoA5 c.457 G>A genotype & 4.600 & 0.032 & 0.464 & $0.230-0.936$ \\
\hline & ApoC3 3238C>G genotype & 4.284 & 0.038 & 2.088 & $1.040-4.193$ \\
\hline \multirow[t]{2}{*}{ ApoA1/ApoB } & ApoC3 3238C>G allele & 6.836 & 0.009 & 0.354 & $0.163-0.771$ \\
\hline & ApoA1 -75bp G>A allele & 3.939 & 0.047 & 6.065 & $1.023-35.968$ \\
\hline \multicolumn{6}{|l|}{ Female } \\
\hline $\mathrm{TC}$ & ApoA5 -1131T>C allele & 19.701 & 0.000 & 2.651 & $1.724-4.078$ \\
\hline TG & ApoC3 3238C>G genotype & 26.171 & 0.000 & 3.149 & $2.029-4.887$ \\
\hline \multirow[t]{5}{*}{ ApoB } & ApoA5 c.457 G>A allele & 7.720 & 0.005 & 2.961 & $1.377-6.368$ \\
\hline & ApoA5 -1131T>C genotype & 5.390 & 0.020 & 1.600 & $1.076-2.379$ \\
\hline & ApoC3 3238C>G allele & 14.382 & 0.000 & 3.403 & $1.807-6.407$ \\
\hline & ApoA1 -75bp G>A genotype & 6.842 & 0.009 & 3.043 & $1.322-7.007$ \\
\hline & ApoA1 -75bp G>A allele & 4.409 & 0.036 & 0.318 & $0.109-0.927$ \\
\hline \multirow[t]{4}{*}{ ApoA1/ApoB } & ApoA5 -1131T>C genotype & 7.771 & 0.005 & 6.339 & $1.730-23.221$ \\
\hline & ApoC3 3238C>G allele & 5.542 & 0.019 & 13.522 & $1.546-118.228$ \\
\hline & ApoA1 -75bp G>A genotype & 5.519 & 0.019 & 14.950 & $1.566-142.771$ \\
\hline & ApoA1 -75bp G>A allele & 7.989 & 0.005 & 0.017 & $0.001-0.287$ \\
\hline
\end{tabular}

TC, total cholesterol; TG, triglyceride; HDL-C, high-density lipoprotein cholesterol; LDL-C, low-density lipoprotein cholesterol; ApoA1, apolipoprotein A1; ApoB, apolipoprotein $B$; ApoA1/ApoB, the ratio of apolipoprotein $A 1$ to apolipoprotein $B$

There exists significant racial variation of allelic frequencies in this gene cluster, but the present study shows that there was no significant difference in the allelic and genotypic frequencies of the all SNPs except ApoC3 3238C >G between males and females. The frequency of ApoC3 $3238 \mathrm{G}$ allele was lower in males than in females $(29.3 \%$ vs. $35.3 \%, P<0.01)$. The frequency of CG and GG genotypes was also lower in males than in females $(P<0.01)$. The frequency of ApoA1 -75bp A allele was higher in our population than in Liangshan $\mathrm{Yi}$ (23.0\%), the other minority in China [46], and Caucasians (12.4-21.8\%) in the western countries [47,48]. Rare allelic frequency of Caucasians from different nations was similar and significantly lower than that of oriental races. The frequency of ApoC3 3238G allele in our population was consistent with ranges reported for Chinese (30-43\%) [29,49], Japanese (25-48\%) [50] and Indians (36\%) [51], but are higher than that reported for Caucasians in whom the $\mathrm{G}$ allele frequency was $0-11 \%$ $[51,52]$. The ApoA5 - $1131 \mathrm{C}$ allele in our study population was similar to that in Chinese (29.9\%) [53,54], Singaporean Chinese (29.4\%) [55], Malays (30.0\%) [55], slightly lower than that in Japanese (34.0\%) [56,57], but much greater than that of whites (8.0\%) [12], Hispanic Americans (16.0\%) [16,58,59] or Tunisian (13.0\%) [60]. The frequency of ApoA5 c.553T allele in this study is extremely low, and is in agreement with that of two previous studies in Chinese (3.97\%) [61] and Chinese 
Table 6 Correlation between serum lipid parameters and several environmental factors in the males and females

\begin{tabular}{|c|c|c|c|c|c|}
\hline Lipid parameter & Risk factor & $\chi^{2}$ & $P$ & Odds ratio & $95 \% \mathrm{Cl}$ \\
\hline \multicolumn{6}{|l|}{ Male plus female } \\
\hline \multirow[t]{5}{*}{$\mathrm{TC}$} & Age & 53.062 & 0.000 & 1.034 & $1.025-1.043$ \\
\hline & Height & 8.532 & 0.003 & 0.847 & $0.757-0.947$ \\
\hline & Weight & 10.525 & 0.001 & 1.329 & $1.119-1.578$ \\
\hline & Body mass index & 6.797 & 0.009 & 0.593 & $0.401-0.878$ \\
\hline & Cigarette smoking & 6.455 & 0.011 & 0.748 & $0.598-0.936$ \\
\hline \multirow[t]{5}{*}{ TG } & Age & 6.792 & 0.009 & 1.017 & $1.004-1.029$ \\
\hline & Height & 16.601 & 0.000 & 0.777 & $0.688-0.877$ \\
\hline & Weight & 16.820 & 0.000 & 1.476 & $1.225-1.778$ \\
\hline & Body mass index & 9.241 & 0.002 & 0.522 & $0.343-0.794$ \\
\hline & Alcohol consumption & 10.147 & 0.001 & 1.606 & $1.200-2.149$ \\
\hline \multirow[t]{5}{*}{ LDL-C } & Ethnic group & 10.381 & 0.001 & 0.492 & $0.320-0.758$ \\
\hline & Sex & 5.359 & 0.021 & 1.728 & $1.088-2.747$ \\
\hline & Age & 28.500 & 0.000 & 1.038 & $1.024-1.052$ \\
\hline & Weight & 44.497 & 0.000 & 1.099 & $1.069-1.129$ \\
\hline & Alcohol consumption & 4.813 & 0.028 & 0.702 & $0.511-0.963$ \\
\hline \multirow[t]{4}{*}{ ApoA1 } & Height & 13.117 & 0.000 & 1.451 & $1.186-1.775$ \\
\hline & Weight & 9.403 & 0.002 & 0.719 & $0.583-0.888$ \\
\hline & Diastolic blood pressure & 7.697 & 0.006 & 0.892 & $0.822-0.967$ \\
\hline & Cigarette smoking & 6.813 & 0.009 & 7.213 & $1.636-13.806$ \\
\hline \multirow[t]{5}{*}{ ApoB } & Sex & 4.652 & 0.031 & 0.665 & $0.459-0.963$ \\
\hline & Height & 4.215 & 0.040 & 0.903 & $0.819-0.995$ \\
\hline & Weight & 5.765 & 0.016 & 1.213 & $1.036-1.419$ \\
\hline & Body mass index & 4.364 & 0.037 & 0.678 & $0.471-0.976$ \\
\hline & Alcohol consumption & 5.787 & 0.016 & 0.744 & $0.585-0.947$ \\
\hline \multirow[t]{4}{*}{ ApoA1/ApoB } & Ethnic group & 3.987 & 0.046 & 1.752 & $1.010-3.037$ \\
\hline & Height & 9.623 & 0.002 & 0.815 & $0.716-0.927$ \\
\hline & Weight & 12.059 & 0.001 & 1.451 & $1.176-1.791$ \\
\hline & Body mass index & 14.889 & 0.000 & 0.374 & $0.227-0.616$ \\
\hline \multicolumn{6}{|l|}{ Male } \\
\hline \multirow[t]{3}{*}{$\mathrm{TC}$} & Age & 5.116 & 0.024 & 1.016 & $1.002-1.031$ \\
\hline & Height & 5.474 & 0.019 & 0.956 & $0.921-0.993$ \\
\hline & Weight & 26.172 & 0.000 & 1.113 & $1.068-1.160$ \\
\hline \multirow[t]{3}{*}{ TG } & Weight & 20.023 & 0.000 & 1.152 & $1.083-1.226$ \\
\hline & Diastolic blood pressure & 4.879 & 0.027 & 0.967 & $0.938-0.996$ \\
\hline & Alcohol consumption & 14.437 & 0.000 & 2.291 & $1.494-3.513$ \\
\hline \multirow[t]{4}{*}{ LDL-C } & Ethnic group & 5.224 & 0.022 & 0.449 & $0.226-0.892$ \\
\hline & Age & 8.301 & 0.004 & 1.035 & $1.011-1.060$ \\
\hline & Height & 14.963 & 0.000 & 1.096 & $1.046-1.148$ \\
\hline & Body mass index & 22.094 & 0.000 & 1.418 & $1.226-1.640$ \\
\hline \multirow[t]{2}{*}{ ApoA1 } & Height & 6.700 & 0.010 & 18.279 & $2.025-5.008$ \\
\hline & Weight & 6.201 & 0.013 & 0.022 & $0.001-0.442$ \\
\hline \multirow[t]{5}{*}{ ApoB } & Height & 4.635 & 0.031 & 0.866 & $0.760-0.987$ \\
\hline & Weight & 5.439 & 0.020 & 1.285 & $1.041-1.587$ \\
\hline & Body mass index & 4.398 & 0.036 & 0.576 & $0.345-0.965$ \\
\hline & Systolic blood pressure & 9.347 & 0.002 & 1.026 & $1.009-1.044$ \\
\hline & Alcohol consumption & 4.211 & 0.040 & 0.736 & $0.549-0.986$ \\
\hline ApoA1/ApoB & Ethnic group & 4.973 & 0.026 & 2.286 & $1.105-4.731$ \\
\hline \multicolumn{6}{|l|}{ Female } \\
\hline \multirow[t]{2}{*}{ TC } & Age & 46.796 & 0.000 & 1.051 & $1.036-1.066$ \\
\hline & Weight & 6.720 & 0.010 & 1.040 & $1.010-1.071$ \\
\hline
\end{tabular}


Table 6 Correlation between serum lipid parameters and several environmental factors in the males and females (Continued)

\begin{tabular}{|c|c|c|c|c|c|}
\hline \multirow[t]{5}{*}{ TG } & Age & 8.060 & 0.005 & 1.028 & $1.009-1.048$ \\
\hline & Height & 14.564 & 0.000 & 0.648 & $0.519-0.810$ \\
\hline & Weight & 13.307 & 0.000 & 1.956 & $1.364-2.805$ \\
\hline & Body mass index & 9.570 & 0.002 & 0.288 & $0.131-0.643$ \\
\hline & Systolic blood pressure & 5.469 & 0.019 & 1.024 & $1.004-1.045$ \\
\hline $\mathrm{HDL}-\mathrm{C}$ & Systolic blood pressure & 3.389 & 0.048 & 0.870 & $0.758-0.999$ \\
\hline \multirow[t]{4}{*}{ LDL-C } & Ethnic group & 5.274 & 0.022 & 0.506 & $0.283-0.905$ \\
\hline & Age & 14.902 & 0.000 & 1.038 & $1.018-1.058$ \\
\hline & Height & 5.072 & 0.024 & 1.061 & $1.008-1.116$ \\
\hline & Body mass index & 11.305 & 0.001 & 1.175 & $1.070-1.291$ \\
\hline \multirow[t]{3}{*}{ ApoA1 } & Weight & 4.470 & 0.034 & 0.258 & $0.074-0.906$ \\
\hline & Systolic blood pressure & 6.152 & 0.013 & 0.583 & $0.380-0.893$ \\
\hline & Pulse pressure & 5.363 & 0.021 & 1.526 & $1.067-2.183$ \\
\hline \multirow[t]{5}{*}{ ApoB } & Age & 14.358 & 0.000 & 1.032 & $1.015-1.049$ \\
\hline & Weight & 5.156 & 0.023 & 1.460 & $1.053-2.023$ \\
\hline & Body mass index & 4.428 & 0.035 & 0.462 & $0.225-0.948$ \\
\hline & Pulse pressure & 4.620 & 0.032 & 0.975 & $0.952-0.998$ \\
\hline & Cigarette smoking & 4.129 & 0.042 & 0.303 & $0.096-0.959$ \\
\hline \multirow[t]{5}{*}{ ApoA1/ApoB } & Age & 6.236 & 0.013 & 1.037 & $1.008-1.067$ \\
\hline & Height & 9.500 & 0.002 & 0.547 & $0.373-0.803$ \\
\hline & Weight & 9.508 & 0.002 & 2.833 & $1.461-5.492$ \\
\hline & Body mass index & 11.423 & 0.001 & 0.080 & $0.019-0.346$ \\
\hline & Pulse pressure & 5.817 & 0.016 & 0.942 & $0.897-0.989$ \\
\hline
\end{tabular}

TC, total cholesterol; TG, triglyceride; HDL-C, high-density lipoprotein cholesterol; LDL-C, low-density lipoprotein cholesterol; ApoA1, apolipoprotein A1; ApoB, apolipoprotein $B$; ApoA1/ApoB, the ratio of apolipoprotein $A 1$ to apolipoprotein $B$

Taiwanese (4.2-7.2\%) [62,63]. The ApoA5 c.553T allele has been reported to be absent in Caucasians [64]. The ApoA5 c.553TT homozygous was not detected in our study population. This is similar to the results in a previous study [61]. The frequency of ApoA5 c.457A allele was lower in our study population than in Chinese Taiwanese $(10.27 \%)$ [54], but was higher than that reported for Czechoslovakians in whom the ApoA5 c.457A allele frequency was $2.04 \%$ [65]. These results suggest that there exists significant racial/ethinc variation of allelic frequencies in the ApoA1/C3/A5 gene cluster.

The association of the ApoA1/C3/A5 gene polymorphisms and plasma or serum lipid levels in humans has been evaluated in a large number of studies [13-30]. However, previous findings are inconsistent [31-38]. Talmud et al. [66] found that the ApoA1 -75 bp A allele induced elevated HDL-C and ApoA1 levels. This relationship was also demonstrated in many other studies, but with sex-dependent: Jeenah et al. [67] and Sigurdsson et al. [68] found in British and Icelandic male respectively that $\mathrm{A}$ allele confered high serum ApoA1 levels. Xu et al. [69] reported A allele carriers had higher mean levels of TC, LDL-C, ApoB and ApoA1 than G homozygotes in Italian boys. Nevertheless, Pagani et al. [70] discovered A allele was positively related to HDL-C concentration in Italian female exclusively. There were also some studies detecting no correlation between the ApoA1 -75 bp G>A and serum lipids pattern [31,32]. Previous cohort studies, as well as case-control and familial studies have shown significant association between the ApoC3 3238G allele and higher plasma TG levels [13-30]. However, several reports failed to find a significant genetic effect on TG concentrations [33-35]. In a previous work, Kee and coworkers found no association between ApoC3 3238C >G polymorphism and lipids, lipoproteins and complex lipoprotein particles in a sample of men from northern France [34]. They thought that the ApoC3 3238C $>$ G polymorphism is not major contributors to the risk of dyslipidemia in the population of northern France. Several separate clinical studies have provided consistent and strong support for the effect with $24 \%$ of whites, $35 \%$ of blacks, and $53 \%$ of Hispanics who carry ApoA5 -1131C allele associated with increased plasma TG levels $[12,16,58]$. But this association was not significant in a population-based Spanish control group [38]. The ApoA5 c.553G $>$ T polymorphism has been found to correlate strongly with TG levels in Chinese but not in Caucasians $[62,64]$. The ApoA5 c.553T allele carriers had significantly higher plasma TG levels compared to the wide-type GG 
genotype, in both CAD and control groups. In a previous study, however, Tang et al. [61] did not find any significant associations between the ApoA5 c.553G>T polymorphism and plasma lipid parameters such as $\mathrm{TC}$, LDL-C, HDL-C, ApoA1, and ApoB in Han Chinese recruited from Jiangsu Province, People's Republic of China. The association of the ApoA5 c.457G >A polymorphism and plasma lipid levels in humans has not been fully elucidated. In a previous study, Kao et al. [62] showed that the ApoA5 c.457G>A polymorphism was not associated with serum TG levels in normal people. In another recent study, Hubacek et al. [65] showed that the impact of statin treatment on lipid parameters did not significantly differ between carriers of the genotypes defined by the ApoA5 c.457G > A polymorphisms. In the present study, we showed that the ApoA5 c.457A allele carriers in males had lower serum HDL-C and ApoA1 levels than the A allele noncarriers, whereas the ApoA5 c.457A allele carriers in females had lower serum TC, LDL-C and ApoB levels and higher the ratio of ApoA1 to ApoB than the A allele noncarriers.

Important intra- and inter-genic LD associations have been found in this study, which replicate previous findings [26-30]. These LD patterns in ApoA1/C3/A5 are rather complex and highly specific to the population under study and indicate the functional dependencies of the encoded proteins [24]. In the present study, haplotype analysis with all five SNPs further supports the strong association between ApoA1/C3/A5 gene polymorphisms and serum lipid levels in our study population. At the global level, the haplotypes comprised of all five SNPs were significantly associated with all seven lipid traits after correcting for multiple testing by permuation test. In particular, haplotype G-G-C-C-A and GA-T-C-G showed consistent association with LDL-C, TC, ApoA1, ApoB, and the ratio of ApoA1 to ApoB. In addition, carriers of haplotype G-G-T-C-G had increased serum concentration of HDL-C and ApoA1, whereas carriers of G-G-C-G-G had high concentrations of TG, TC, and ApoB. We also found that haplotypes with five SNPs explain much more serum lipid variation than any single SNP alone, especially for TG and HDL-C.

The present study has some shortcomings. Firstly, the size of our study population is a bit small, which might not have had the power to detect the LD across the ApoA1/C3/A5 locus. The individual with ApoA5 c.553TT genotype is not detected in our population, and the number of subjects with ApoA5 c.457AA genotype in both sexes is also small. It has been postulated that an adequate analysis of the polymorphic variants of the ApoA1/ ApoC3/ApoA4 gene complex requires a sample of at least 600 subjects to allow the detection of a twofold increased risk of disease [71]. Secondly, the levels of body height, weight, systolic blood pressure, diastolic blood pressure, pulse pressure, the prevalence of hypertension, and the percentages of subjects who consumed alcohol or smoked cigarettes were higher in males than in femailes. Although age, BMI, blood pressure, alcohol consumption, and cigarette smoking have been adjusted for the statistical analysis, we can not completely exclude the influence of these factors on serum lipid levels among different genotypes in both sexes. Thirdly, because we selected the SNPs from literature and did not cover the extensive ApoA1/C3/A4/A5 gene locus, we might miss some information from other SNPs. We did not include ApoA4 SNPs in this study, because there is no ApoA4 SNP is associated with hypertriglyceridemia [29], except ApoA4 T347S associated with a TG-lowering effect [16]. Chien et al. [30] have analyzed amino acid 360 ( $\mathrm{G}$ to $\mathrm{T}$ substitution, Glu to His) and amino acid 347 (A to T, Thr to Ser) of the ApoA4 gene but the results showed no substitution was found in a community-based population.

\section{Conclusion}

The present study shows that the allelic and genotypic frequencies of the all SNPs except ApoC3 3238C>G were not different between males and females, but all five SNPs at the ApoA1/C3/A5 gene cluster and their haplotypes are closely associated with modifications of serum lipid parameters in both sexes. The haplotypes with five SNPs explain much more serum lipid variation than any single SNP alone, especially for TG and HDL$\mathrm{C}$ in the general Chinese population.

\section{Acknowledgements}

This study was supported by the National Natural Science Foundation of China (No: 30360038)

\section{Author details}

${ }^{1}$ Department of Cardiology, Institute of Cardiovascular Diseases, the First Affiliated Hospital, Guangxi Medical University, 22 Shuangyong Road, Nanning 530021, Guangxi, People's Republic of China. ${ }^{2}$ Department of Cardiology, Guangxi National Hospital, Nanning 530001, Guangxi, People's Republic of China. ${ }^{3}$ Nutrition and Genomics Laboratory, Jean Mayer USDA HNRCA at Tufts University, Boston, MA 02111-1524, USA.

\section{Authors' contributions}

RXY conceived the study, participated in the design, carried out the epidemiological survey, collected the samples, performed statistical analyses, and drafted the manuscript. YYL participated in the design, undertook genotyping, and helped to perform statistical analyses. CQL participated in the design, performed statistical analyses, and helped to draft the manuscript. All authors read and approved the final manuscript.

\section{Competing interests}

The authors declare that they have no competing interests.

Received: 14 July 2011 Accepted: 19 August 2011

Published: 19 August 2011

\section{References}

1. Shekelle RB, Shryock AM, Paul O, Lepper M, Stamler J, Liu S, Raynor WJ Jr: Diet, serum cholesterol, and death from coronary heart disease. The Western Electric study. N Engl J Med 1981, 304:65-70. 
2. Austin MA: Plasma triglyceride as a risk factor for coronary heart disease. The epidemiologic evidence and beyond. Am J Epidemiol 1989, 129:249-59.

3. März W, Scharnagl H, Winkler K, Tiran A, Nauck M, Boehm BO, Winkelmann BR: Low-density lipoprotein triglycerides associated with low-grade systemic inflammation, adhesion molecules, and angiographic coronary artery disease: the Ludwigshafen Risk and Cardiovascular Health study. Circulation 2004, 110:3068-74.

4. Kwiterovich PO Jr, Coresh J, Smith HH, Bachorik PS, Derby CA, Pearson TA: Comparison of the plasma levels of apolipoproteins $B$ and $A-1$, and other risk factors in men and women with premature coronary artery disease. Am J Cardiol 1992, 69:1015-21.

5. Hokanson JE, Austin MA: Plasma triglyceride level is a risk factor for cardiovascular disease independent of high-density lipoprotein cholesterol level: a meta-analysis of population-based prospective studies. J Cardiovasc Risk 1996, 3:213-319.

6. Yin RX, Li YY, Liu WY, Zhang L, Wu JZ: Interactions of the apolipoprotein A5 gene polymorphisms and alcohol consumption on serum lipid levels. PLOS ONE 2011, 6:e17954.

7. Heller DA, de Faire U, Pedersen NL, Dahlén G, McClearn GE: Genetic and environmental influences on serum lipid levels in twins. $N$ Engl J Med 1993, 328:1150-6.

8. Li Y, Yin R, Zhou Y, Deng Y, Yang D, Pan S, Lin W: Associations of the apolipoprotein A-I gene polymorphism and serum lipid levels in the Guangxi Hei Yi Zhuang and Han populations. Int J Mol Med 2008, 21:753-64

9. Wang C, McConathy WJ, Kloer HU, Alaupovic P: Modulation of lipoprotein lipase activity by apolipoproteins. J Clin Invest 1985, 75:384-90.

10. O'Brien PJ, Alborn WE, Sloan HJ, Ulmer M, Boodhoo A, Knierman MD, Schultze AE, Konrad1 RJ: The novel apolipoprotein A5 is present in human serum, is associated with VLDL, HDL, and chylomicrons, and circulates at very low concentrations compared with other apolipoproteins. Clin Chem 2005, 51:351-9.

11. Bruns GA, Karanthasis SK, Breslow JL: Human apolipoprotein Al-CIII gene complex is located on chromosome 11. Arteriosclerosis 1984, 4:97-102.

12. Pennacchio LA, Olivier M, Hubacek JA, Cohen JC, Cox DR, Fruchart JC, Krauss RM, Rubin EM: An apolipoprotein influencing triglycerides in humans and mice revealed by comparative sequencing. Science 2001, 294:169-73

13. Ordovas JM, Civeira F, Genest J Jr, Craig S, Robbins AH, Meade T, Pocovi M, Frossard PM, Masharani U, Wilson PW, Salem DN, Ward RH, Schaefer EJ: Restriction fragment length polymorphisms of the apolipoprotein A-I, CIII, A-IV gene locus. Relationships with lipids, apolipoproteins, and premature coronary artery disease. Atherosclerosis 1991, 87:75-86.

14. Hong SH, Park WH, Lee CC, Song JH, Kim JQ: Association between genetic variations of apo Al-CIII-AIV cluster gene and hypertriglyceridemic subjects. Clin Chem 1997, 43:13-7.

15. Song J, Park JW, Park H, Kim JQ: Linkage disequilibrium of the Apo Al-CIIIAIV gene cluster and their relationship to plasma triglyceride, apolipoprotein Al and CIII levels in Koreans. Mol Cells 1998, 8:12-8,

16. Talmud PJ, Hawe E, Martin S, Olivier M, Miller GJ, Rubin EM, Pennacchio LA, Humphries SE: Relative contribution of variation within the APOC3/A4/A5 gene cluster in determining plasma triglycerides. Hum Mol Genet 2002, 11:3039-46.

17. Mar R, Pajukanta P, Allayee H, Groenendijk M, Dallinga-Thie G, Krauss RM, Sinsheimer JS, Cantor RM, de Bruin TW, Lusis AJ: Association of the APOLIPOPROTEIN A1/C3/A4/A5 gene cluster with triglyceride levels and LDL particle size in familial combined hyperlipidemia. Circ Res 2004, 94:993-9.

18. Eichenbaum-Voline S, Olivier M, Jones EL, Naoumova RP, Jones B, Gau B, Patel HN, Seed M, Betteridge DJ, Galton DJ, Rubin EM, Scott J, Shoulders CC, Pennacchio LA: Linkage and association between distinct variants of the APOA1/C3/A4/A5 gene cluster and familial combined hyperlipidemia. Arterioscler Thromb Vasc Biol 2004, 24:167-74.

19. Dallongeville J, Cottel D, Montaye M, Codron V, Amouyel P, Helbecque N: Impact of APOA5/A4/C3 genetic polymorphisms on lipid variables and cardiovascular disease risk in French men. Int J Cardiol 2006, 106:152-6.

20. Hamon SC, Kardia SL, Boerwinkle E, Liu K, Klos KL, Clark AG, Sing CF: Evidence for consistent intragenic and intergenic interactions between SNP effects in the APOA1/C3/A4/A5 gene cluster. Hum Hered 2006, 61:87-96.
21. Klos KL, Sing CF, Boerwinkle E, Hamon SC, Rea TJ, Clark A, Fornage M, Hixson JE: Consistent effects of genes involved in reverse cholesterol transport on plasma lipid and apolipoprotein levels in CARDIA participants. Arterioscler Thromb Vasc Biol 2006, 26:1828-36.

22. Qi L, Liu S, Rifai N, Hunter D, Hu FB: Associations of the apolipoprotein A1/C3/A4/A5 gene cluster with triglyceride and HDL cholesterol levels in women with type 2 diabetes. Atherosclerosis 2007, 192:204-10.

23. Shanker J, Perumal G, Rao VS, Khadrinarasimhiah NB, John S, Hebbagodi S, Mukherjee M, Kakkar W: Genetic studies on the APOA1-C3-A5 gene cluster in Asian Indians with premature coronary artery disease. Lipids Health Dis 2008, 7:33.

24. Delgado-Lista J, Perez-Jimenez F, Ruano J, Perez-Martinez P, Fuentes F, Criado-Garcia J, Parnell LD, Garcia-Rios A, Ordovas JM, Lopez-Miranda J: Effects of variations in the APOA1/C3/A4/A5 gene cluster on different parameters of postprandial lipid metabolism in healthy young men. J Lipid Res 2010, 51:63-73.

25. Liu ZK, Hu M, Baum L, Thomas GN, Tomlinson B: Associations of polymorphisms in the apolipoprotein A1/C3/A4/A5 gene cluster with familial combined hyperlipidaemia in Hong Kong Chinese. Atherosclerosis 2010, 208:427-32.

26. Tahvanainen E, Pajukanta P, Porkka K, Nieminen S, Ikävalko L, Nuotio I, Taskinen MR, Peltonen L, Ehnholm C: Haplotypes of the ApoA-I/C-III/A-IV gene cluster and familial combined hyperlipidemia. Arterioscler Thromb Vasc Biol 1998, 18:1810-7.

27. Wang QF, Liu X, O'Connell J, Peng Z, Krauss RM, Rainwater DL, VandeBerg JL, Rubin EM, Cheng JF, Pennacchio LA: Haplotypes in the APOA1-C3-A4-A5 gene cluster affect plasma lipids in both humans and baboons. Hum Mol Genet 2004, 13:1049-56.

28. Olivier M, Wang X, Cole R, Gau B, Kim J, Rubin EM, Pennacchio LA: Haplotype analysis of the apolipoprotein gene cluster on human chromosome 11. Genomics 2004, 83:912-23.

29. Chien KL, Fang WH, Wen HC, Lin HP, Lin YL, Lin SW, Wu JH, Kao JT: APOA1/C3/A5 haplotype and risk of hypertriglyceridemia in Taiwanese. Clin Chim Acta 2008, 390:56-62.

30. Chien KL, Chen MF, Hsu HC, Su TC, Chang WT, Lee CM, Lee YT: Genetic association study of APOA1/C3/A4/A5 gene cluster and haplotypes on triglyceride and $\mathrm{HDL}$ cholesterol in a community-based population. Clin Chim Acta 2008, 388:78-83.

31. Barre DE, Guerra R, Verstraete R, Wang Z, Grundy SM, Cohen JC: Genetic analysis of a polymorphism in the human apolipoprotein A-I gene promoter: effect on plasma HDL-cholesterol levels. J Lipid Res 1994, 35:1292-6.

32. de Franca E, Alves JG, Hutz MH: APOA1/C3/A4 gene cluster variability and lipid levels in Brazilian children. Braz J Med Biol Res 2005, 38:535-41.

33. Marcil M, Boucher B, Gagné E, Davignon J, Hayden M, Genest J Jr: Lack of association of the apolipoprotein A-I-C-III-A-IV gene Xmnl and Sstl polymorphisms and of the lipoprotein lipase gene mutations in familial combined hyperlipoproteinemia in French Canadian subjects. J Lipid Res 1996, 37:309-19.

34. Kee F, Amouyel P, Fumeron F, Arveiler D, Cambou JP, Evans A, Cambien F, Fruchart JC, Ducimetière $P$, Dallongeville J: Lack of association between genetic variations of apo A-I-C-III-A-IV gene cluster and myocardial infarction in a sample of European male: ECTIM study. Atherosclerosis 1999, 145:187-95.

35. Thu NN, Mai TT, Ohmori R, Kuroki M, Chuyen NV, Hung NT, Kawakami M, Kondo K: Plasma triglyceride and $\mathrm{HDL}-$ cholesterol concentrations in Vietnamese girls are affected by lipoprotein lipase, but not apolipoprotein CIII polymorphism. J Nutr 2006, 136:1488-92.

36. Nieminen T, Kähönen M, Islam S, Raitakari OT, Hutri-Kähönen N, Marniemi J, Juonala M, Rontu R, Viikari J, Lehtimäki T: Apolipoprotein A-I/C-III/A-IV Sstl and apolipoprotein B Xbal polymorphisms do not affect early functional and structural changes in atherosclerosis: the Cardiovascular Risk in Young Finns study. Circ J 2007, 71:741-5.

37. Lee KWJ, Ayyobi AF, Frohlich JJ, Hill JS: APOA5 gene polymorphism modulates levels of triglyceride, HDL cholesterol and FERHDL but is not a risk factor for coronary artery disease. Atherosclerosis 2004, 176:165-72.

38. Ribalta J, Figuera L, Fernandez-Ballart J, Vilella E, Castro Cabezas M, Masana L, Joven J: Newly identified apolipoprotein AV gene predisposes to high plasma triglycerides in familial combined hyperlipidemia. Clin Chem 2002, 48:1597-600. 
39. Ruixing $Y$, Yuming $C$, Shangling $P$, Fengping $H$, Tangwei $L$, Dezhai $Y$, Jinzhen $W$, Limei $Y$, Weixiong $L$, Rongshan $L$, Jiandong $H$ : Effects of demographic, dietary and other lifestyle factors on the prevalence of hyperlipidemia in Guangxi Hei Yi Zhuang and Han populations. Eur J Cardiovasc Prev Rehabil 2006, 13:977-84.

40. Yiyang $L$, Ruixing $Y$, Meng $L$, Kela $L$, Xingjiang $L$, Lin $Z$, Wanying $L$, Shangling P, Dezhai Y, Weixiong L: Apolipoprotein C-III gene polymorphism and several environmental factors with serum lipid levels in the Guangxi Hei Yi Zhuang and Han populations. J Investig Med 2010, 58:777-85.

41. Ruixing $Y$, Limei $Y$, Yuming $C$, Dezhai $Y$, Weixiong $L$, Muyan $L$, Fengping $H$ Jinzhen W, Guangqing Y, Zhenbiao N: Prevalence, awareness, treatment, control and risk factors of hypertension in the Guangxi Hei Yi Zhuang and Han populations. Hypertens Res 2006, 29:423-32

42. Bermudez Ol, Velez-Carrasco W, Schaefer EJ, Tucker KL: Dietary and plasma lipid, lipoprotein, and apolipoprotein profiles among elderly Hispanics and non-Hispanics and their association with diabetes. Am J Clin Nutr 2002, 76:1214-21.

43. Srinivasan SR, Freedman DS, Webber LS, Berenson GS: Black-white differences in cholesterol levels of serum high-density lipoprotein subclasses among children: the Bogalusa Heart Study. Circulation 1987, 76:272-9.

44. Mudali S, Dobs AS, Ding J, Cauley JA, Szklo M, Golden SH, atherosclerosis risk in communities study: Endogenous postmenopausal hormones and serum lipids: the atherosclerosis risk in communities study. J Clin Endocrinol Metab 2005, 90:1202-9.

45. Cheung AP: Acute effects of estradiol and progesterone on insulin, lipids and lipoproteins in postmenopausal women: a pilot study. Maturitas 2000, 35:45-50.

46. Zhao Q, She M, Shen $P$, Zhang $H$, Zhou M: Interaction of alcohol and the $\mathrm{G}$ to $\mathrm{A}$ substitution at the promoter region of the apolipoprotein $\mathrm{Al}$ gene in determining plasma apolipoprotein Al levels in $\mathrm{Yi}$ and Han Chinese. Chin Med J (Engl) 2000, 113:471-4.

47. Paul-Hayase H, Rosseneu M, Robinson D, Van Bervliet JP, Deslypere JP, Humphries SE: Polymorphisms in the apolipoprotein (apo) Al-CIII-AIV gene cluster: detection of genetic variation determining plasma apo $\mathrm{Al}$, apo CIII and apoA IV concentrations. Hum Genet 1992, 88:439-46.

48. Sigurdsson G Jr, Gudnason V, Sigurdsson G, Humphries SE: Interaction between a polymorphism of the apoA-I promoter region and smoking determines plasma levels of HDL and apoA-I. Arterioscler Thromb 1992, 12:1017-22.

49. Ko YL, Ko YS, Wu SM, Teng MS, Chen FR, Hsu TS, Chiang CW, Lee YS: Interaction between obesity and genetic polymorphisms in the apolipoprotein CIII gene and lipoprotein lipase gene on the risk of hypertriglyceridemia in Chinese. Hum Genet 1997, 100:327-33.

50. Bai H, Saku K, Liu R, Imamura M, Arakawa K: Association between coronary heart disease and the apolipoprotein A-I/C-III/A-IV complex in a Japanese population. Hum Genet 1995, 95:102-4.

51. Chhabra S, Narang R, Krishnan LR, Vasisht S, Agarwal DP, Srivastava LM, Manchanda SC, Das N: Apolipoprotein C3 Sstl polymorphism and triglyceride levels in Asian Indians. BMC Genet 2002, 3:9.

52. Russo GT, Meigs JB, Cupples LA, Demissie S, Otvos JD, Wilson PW, Lahoz C, Cucinotta D, Couture P, Mallory T, Schaefer EJ, Ordovas JM: Association of the Sst-I polymorphism at the APOC3 gene locus with variations in lipid levels, lipoprotein subclass profiles and coronary heart disease risk: the Framingham offspring study. Atherosclerosis 2001, 158:173-81.

53. Baum L, Tomlinson B, Thomas GN: ApoA5 -1131T $>C$ polymorphism is associated with triglyceride levels in Chinese men. Clin Genet 2003 63:377-9.

54. Liu H, Zhang S, Lin J, Li H, Huang A, Xiao C, Li X, Su Z, Wang C, Nebert DW Zhou B, Zheng K, Shi J, Li G, Huang D: Association between DNA variant sites in the apolipoprotein A5 gene and coronary heart disease in Chinese. Metabolism 2005, 54:568-72.

55. Lai CQ, Tai ES, Tan CE, Cutter J, Chew SK, Zhu YP, Adiconis X, Ordovas JM: The ApoA5 locus is a strong determinant of plasma triglyceride concentrations across ethnic groups in Singapore. J Lipid Res 2003, 44:2365-73.

56. Endo K, Yanagi H, Araki J, Hirano C, Yamakawa-Kobayashi K, Tomura S: Association found between the promoter region polymorphism in the apolipoprotein $\mathrm{A}-\mathrm{V}$ gene and the serum triglyceride level in Japanese schoolchildren. Hum Genet 2002, 111:570-2.
57. Nabika T, Nasreen S, Kobayashi S, Masuda J: The genetic effect of the apoprotein AV gene on the serum triglyceride level in Japanese. Atherosclerosis 2002, 165:201-4.

58. Pennacchio LA, Olivier M, Hubacek JA, Krauss RM, Rubin EM, Cohen JC: Two independent apolipoprotein A5 haplotypes influence human plasma triglyceride levels. Hum Mol Genet 2001, 11:3031-8.

59. Aouizerat BE, Kulkarni M, Heilbron D, Drown D, Raskin S, Pullinger CR, Malloy MJ, Kane JP: Genetic analysis of a polymorphism in the human apoA-V gene: effect on plasma lipids. J Lipid Res 2003, 44:1167-73.

60. Chaaba R, Attia N, Hammami S, Smaoui M, Mahjoub S, Hammami M, Masmoudi AS: Association of SNP3 polymorphism in the apolipoprotein A-V gene with plasma triglyceride level in Tunisian type 2 diabetes. Lipids Health Dis 2005, 4:1.

61. Tang Y, Sun P, Guo D, Ferro A, Ji Y, Chen Q, Fan L: A genetic variant c.553G $>T$ in the apolipoprotein A5 gene is associated with an increased risk of coronary artery disease and altered triglyceride levels in a Chinese population. Atherosclerosis 2006, 185:433-7.

62. Kao JT, Wen HC, Chien KL, Hsu HC, Lin SW: A novel genetic variant in the apolipoprotein A5 gene is associated with hypertriglyceridemia. Hum Mol Genet 2003, 12:2533-9.

63. Hsu LA, Ko YL, Chang CJ, Hu CF, Wu S, Teng MS, Wang CL, Ho WJ, Ko YS, Hsu TS, Lee YS: Genetic variations of apolipoprotein A5 gene is associated with the risk of coronary artery disease among Chinese in Taiwan. Atherosclerosis 2006, 185:143-9.

64. Hubácek JA, Adámková V, Ceska R, Poledne R, Horínek A, Vráblík M: New variants in the apolipoprotein AV gene in individuals with extreme triglyceride levels. Physiol Res 2004, 53:225-8.

65. Hubacek JA, Adamkova V, Prusikova M, Snejdrlova M, Hirschfeldova K, Lanska V, Ceska R, Vrablik M: Impact of apolipoprotein A5 variants on statin treatment efficacy. Pharmacogenomics 2009, 10:945-50.

66. Talmud PJ, Ye S, Humphries SE: Polymorphism in the promoter region of the apolipoprotein Al gene associated with differences in apolipoprotein Al levels: the European Atherosclerosis research study. Genet Epidemiol 1994, 11:265-80.

67. Jeenah M, Kessling A, Miller N, Humphries SE: G to A substitution in the promoter region of the apolipoprotein $\mathrm{Al}$ gene is associated with elevated serum apolipoprotein $\mathrm{Al}$ and high density lipoprotein cholesterol concentrations. Mol Biol Med 1990, 7:233-41.

68. Sigurdsson G Jr, Gudnason V, Sigurdsson G, Humphries SE: Interaction between a polymorphism of the apoA-I promoter region and smoking determines plasma levels of HDL and apoA-I. Arterioscler Thromb 1992, 12:1017-22.

69. Xu CF, Angelico F, Del Ben M, and Humphries SE: Role of genetic variation at the apoAI-CIII-AIV gene cluster in determining plasma apoA-I levels in boys and girls. Genet Epidermiol 1993, 10:113-22.

70. Pagani F, Sidoli A, Giudici GA, Barenghi L, Vergani C, Baralle FE: Human apolipoprotein A-I gene promoter polymorphism: association with hyperalphalipoproteinemia. J Lipid Res 1990, 31:1371-7.

71. Humphries S, Talmud P, Monsalve V, McKeigue P: RFLP studies in different ethnic groups. Atherosclerosis 1989, 75:249-50.

doi:10.1186/1476-511X-10-140

Cite this article as: Yin et al:: Apolipoprotein A1/C3/A5 haplotypes and serum lipid levels. Lipids in Health and Disease 2011 10:140.

\section{Submit your next manuscript to BioMed Central and take full advantage of:}

- Convenient online submission

- Thorough peer review

- No space constraints or color figure charges

- Immediate publication on acceptance

- Inclusion in PubMed, CAS, Scopus and Google Scholar

- Research which is freely available for redistribution 